\title{
Highly Branched Unsaturated Polyethylenes Achievable Using Strained Imino-cyclopenta[b]pyridyl-nickel Precatalysts
}

Received 00th January 20xx, Accepted 00th January 20xx DOI: $10.1039 / \times 0 x \times 00000 x$ www.rsc.org/

\author{
Youfu Zhang, ${ }^{a, b}$ Chuanbing Huang, ${ }^{b, c}$ Xinxin Wang, ${ }^{b, c}$ Qaiser Mahmood, ${ }^{b, c}$ Xiang Hao, ${ }^{b}$ Xinquan Hu, ${ }^{*, a}$ \\ Cun-Yue Guo, ${ }^{*, c}$ Gregory A. Solan, ${ }^{*, b, d}$ and Wen-Hua Sun*,b,c,e
}

\section{Introduction}

With the aim of introducing subtle control over the microstructure of a polyethylene, late transition metal $\alpha$ diimino-nickel/palladium ${ }^{1}$ and bis(imino)pyridyl-iron/cobalt precatalysts $^{2}$ have shown great promise for realizing this goal. For instance, the polyolefinic materials generated by nickel precatalysts can show branching properties that are a characteristic of linear low density polyethylene, ${ }^{1}$ while linear high density polyethylene is a hallmark of the materials obtained by the bis(imino)pyridyl-iron/cobalt precatalysts. ${ }^{2 b, 2 d}$ With a view to gaining a deeper understanding of the mechanism of polymerization, coupled with the growing commercial applications of these polyethylene grades, research groups in both industry and in academia have been exploring the effects of modifications to the ligand framework the nature of the late transition metal center and/or the polymerization conditions. ${ }^{1 f, 3}$ In this regard, $\alpha$-diimino-nickel systems have been at the forefront of many of the key developments.

With an eye to developing new or improved polyethylene properties through microstructural modifications, we have

${ }^{a}$ College of Chemical Engineering, Zhejiang University of

Technology, Hangzhou 310014, China.Email: xinquan@zjut.edu.cn

${ }^{b}$ Key laboratory of Engineering Plastics and Beijing National

Laboratory for Molecular Science, Institute of Chemistry, Chinese

Academy of Sciences, Beijing 100190, China. Email:

whsun@iccas.ac.cn

'School of Chemistry and Chemical Engineering, University of

Chinese Academy of Sciences, Beijing 100049, China. E-mail:

cyguo@ucas.ac.cn

${ }^{d}$ Department of Chemistry, University of Leicester, University Road,

Leicester LE1 7RH, UK. E-mail: gas8@leicester.ac.uk

e State Key Laboratory for Oxo Synthesis and Selective Oxidation,

Lanzhou Institute of Chemical Physics, Chinese Academy of

Sciences, Lanzhou 730000, China.

+ Electronic Supplementary Information (ESI) available: Ethylen

polymerization with Ni1-Ni4/MMAO; and CCDC 1519413

and1519414for complexes Ni1and Ni2. See

DOI: $10.1039 / x 0 \times x 00000 x$ disclosed a range of cycloalkyl-fused pyridine ligand sets that have served as compatible chelating supports for a variety of nickel(II) precatalysts including 8-arylimino-5,6,7trihydroquinolynickel (A, Chart 1$)^{4,5}$ and 9-arylimino-5,6,7,8tetrahydrocyclohepta[b]pyridyl-nickel (B, Chart 1). ${ }^{6}$ Indeed A and $\mathbf{B}$ not only display high activities but also confer some distinct effects on the structural properties of the so-formed polyethylenes. These effects being ascribed to the cyclictension imparted by the presence of the respective cyclohexyl and cycloheptyl fused rings present within the ligand frame. For example, the use of $\mathbf{B}$ leads to a higher branching content when compared with $\mathbf{A}$, while both display similar polyethylene molecular weights. ${ }^{4 a, 5}$ Moreover, variations in the electronic and steric influences notably affect the degree of branching, particularly with respect to the long chain branches. ${ }^{4 \mathrm{~b}, 4 \mathrm{c}}$ By contrast nickel precatalysts containing the smaller cyclopentyl counterparts have proved more synthetically challenging. Indeed, difficulties associated with the preparation of 7-aryliminocyclopenta[b]pyridines from their cyclopenta[b]pyridine-7-one precursor have so far precluded their synthesis; an observation that is likely due to imine-enamine tautomerization in the product and ensuing decomposition pathways. ${ }^{7}$ To block this tautomerization, we have developed related precatalysts incorporating multiple substitutions at the $\alpha$-carbon to the imine. For example, the gem-dimethyl containing cobalt and chromium complexes $\mathbf{C}$ (Chart 1) can readily be synthesized,7,8 and moreover these precatalysts mediate the formation of polyethylenes with narrow polydispersity and high linearity. $4,7,8$ Similar gemdimethyl substitution is also possible in the cyclohexylcontaining nickel complex $\mathbf{D}(\text { Chart } 1)^{9}$ and again high activity and single-site behavior are a feature. Furthermore, when compared with $\mathbf{A},{ }^{4 a} \mathbf{D}$ affords polyethylene waxes exhibiting lower molecular weight and higher levels of branching, including a higher ratio of long chain branches. 

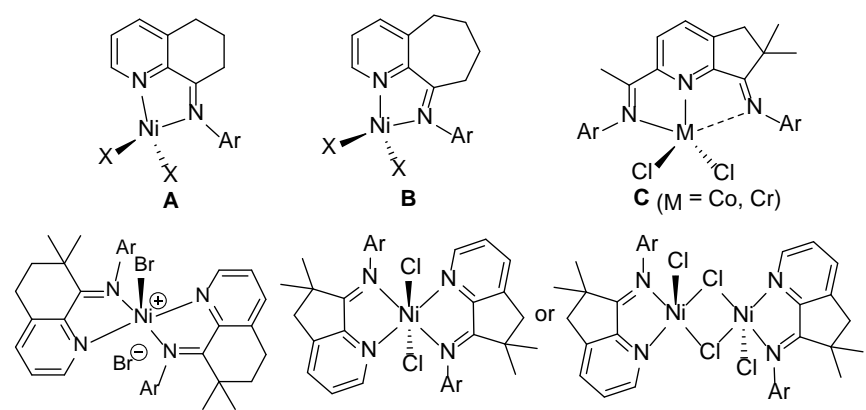

this work

Chart 1 Representative examples of cycloalkyl-fused iminopyridyl-metal precatalysts

In this report, we develop the dialkyl-substitution strategy by applying it to the synthesis of a range of 7-arylimino-6,6dimethylcyclopenta[b]pyridyl-nickel complexes (Chart 1). On activation with either MAO or MMAO, these precatalysts exhibit high activities towards ethylene polymerization and produce polymers with lower molecular weight, narrower polydispersities and a higher ratio of long chain branches when compared with cyclohexyl-containing $\mathbf{D}$ (Chart 1 ). ${ }^{9}$ A detailed microstructural study of the polyethylenes is reported using high temperature ${ }^{1} \mathrm{H}$ NMR, ${ }^{13} \mathrm{C}$ NMR and DEPT135 ${ }^{13} \mathrm{C} N M R$ spectroscopy. Interestingly, the unsaturated content within the resultant polyethylenes is clearly observable with both vinyl and vinylene groups apparent. To the best of our knowledge, this is the first disclosure of such polyolefinic materials being generated in an ethylene homopolymerization using a single metal catalyst, with copolymerization of ethylene and 1-alkene representing the alternative previous approach. ${ }^{10}$ Besides, such polyethylene macromers are in high demand for long chain branched copolymers, functionally modifiable polymers as well as coating materials. ${ }^{11}$ We also present a mechanism that accounts for the observed microstructural properties, while the approximate number of regenerated active species are evaluated on the basis of the molecular weight of the polyethylene obtained.

\section{Results and discussion}

\section{Synthesis and characterization}

The imino-cyclopenta[b]pyridines, 7-( $\mathrm{ArN})-6-\mathrm{Me}_{2} \mathrm{C}_{8} \mathrm{H}_{5} \mathrm{~N}(\mathrm{Ar}=$ 2,6- $\mathrm{Me}_{2} \mathrm{Ph}$ (L1), 2,6-Et ${ }_{2} \mathrm{Ph}$ (L2), 2,4,6- $\mathrm{Me}_{3} \mathrm{Ph}$ (L3), 2,6- $\mathrm{Et}_{2}-4-$ MePh (L4), 2,6-i- $\mathrm{Pr}_{2} \mathrm{Ph}$ (L5)), could be prepared by the Schiff base condensation of 2-chloro-6,6dimethylcyclopenta[b]pyridin-7-one (3) with the corresponding aniline in 0 -dichlorobenzene in good yields (Scheme 1). ${ }^{a}, 7,12$ Ketone $\mathbf{3}$ is not commercially available and was synthesized in a two-step procedure by firstly gemdimethylating 2-chloro-cyclopenta[b]pyridin-7-one $(\mathbf{1})^{7}$ at the 6-position to give 2-chloro-6,6-dimethylcyclopenta[b]pyridin-7one (2) and then $\mathbf{2}$ could be de-chlorinated to form $\mathbf{3}$ by its hydrogenation in the presence of palladium on carbon. All the organic compounds were characterized by ${ }^{1} \mathrm{H} N M R,{ }^{13} \mathrm{C} N M R$ and FT-IR spectroscopies and elemental analyses.
Treatment of $\mathrm{NiCl}_{2} \cdot 6 \mathrm{H}_{2} \mathrm{O}$ with an equimolar ratio of $\mathbf{L 1}$ and L3 in a mixture of dichloromethane and ethanol gave, on workup, mononuclear [7-(ArN)-6- $\left.\mathrm{Me}_{2} \mathrm{C}_{8} \mathrm{H}_{5} \mathrm{~N}\right]_{2} \mathrm{NiCl}_{2}\left(\mathrm{Ar}=2,6-\mathrm{Me}_{2} \mathrm{Ph}\right.$ (Ni1), 2,4,6- $\mathrm{Me}_{3} \mathrm{Ph}(\mathrm{Ni3})$ ), while with $\mathbf{L 2}$ and L4, the binuclear species [7-(ArN)-6- $\left.\mathrm{Me}_{2} \mathrm{C}_{8} \mathrm{H}_{5} \mathrm{~N}\right]_{2} \mathrm{Ni}_{2}(\mu-\mathrm{Cl})_{2} \mathrm{Cl}_{2} \quad\left(\mathrm{Ar}=2,6-\mathrm{Et}_{2} \mathrm{Ph}\right.$ (Ni2), 2,6-Et ${ }_{2}-4-\mathrm{MePh}(\mathrm{Ni4})$ ), have been isolated in reasonable yield (Scheme 1). Unexpectedly, no isolable nickel complex could be obtained on reaction with $\mathbf{L 5}$, which may be due to the steric hindrance imparted by the ortho-isopropyl groups. ${ }^{9}$ Complexes Ni1 - Ni4 were characterized by FT-IR spectroscopy, elemental analysis as well as by ESI mass spectrometry, while Ni1 and Ni2 were the subject of single crystal X-ray diffraction studies.

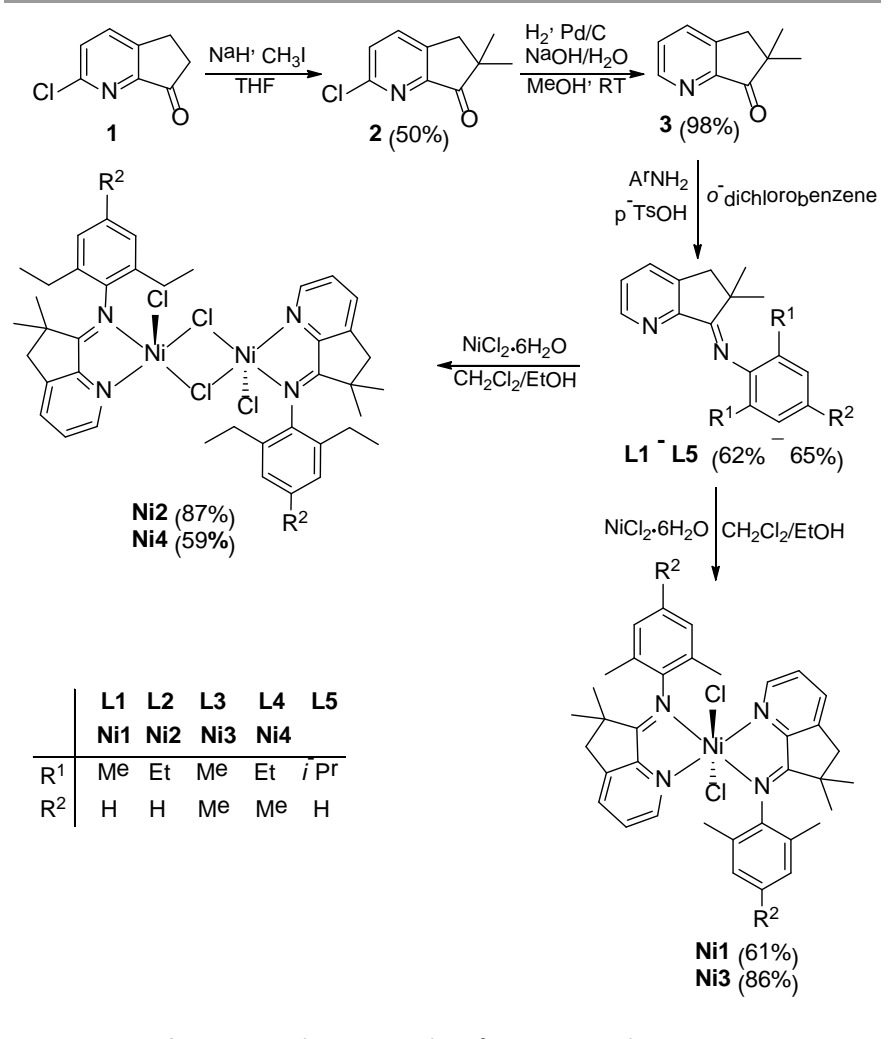

Scheme 1 Synthetic procedure for L1 - L5 and Ni1 - Ni4

The FT-IR spectra of $\mathbf{N i 1}$ - Ni4 showed the $v(\mathrm{C}=\mathrm{N})_{\text {imine }}$ stretching vibrations to appear in the range $1635-1639 \mathrm{~cm}^{-1}$, which compares to $1672-1680 \mathrm{~cm}^{-1}$ in the free ligands, highlighting the effective coordination of the $\mathrm{N}_{\text {imino }}$ donor to the nickel atom. The mass spectra of the complexes show fragmentation peaks corresponding to the loss of a chloride ligand from the respective molecular ion. In addition, their elemental analyses are in agreement with the proposed structures for $\mathbf{N i 1}-\mathbf{N i 4}$.

Single crystals of $\mathbf{N i} 1$ and $\mathbf{N i 2}$ suitable for the X-ray diffraction determinations were obtained by slow diffusion of diethyl ether into methanol solutions containing the corresponding complex. The structures of the two complexes are different and will be discussed separately. Views of Ni1 and $\mathbf{N i} 2$ are shown in Figs. 1 and 2 respectively; selected bond lengths and angles are tabulated for both in Table 1.

Table 1 Selected bond lengths $(\AA)$ and angles $\left({ }^{\circ}\right)$ for $\mathrm{Ni1}$ and $\mathrm{Ni2}$ 


\begin{tabular}{|c|c|c|c|}
\hline \multicolumn{2}{|c|}{ Ni1 } & \multicolumn{2}{|c|}{ Ni2 } \\
\hline \multicolumn{4}{|c|}{ Bond lengths (Å) } \\
\hline $\mathrm{Ni}(1)-\mathrm{N}(1)$ & $2.2952(14)$ & $\mathrm{Ni}(1)-\mathrm{N}(1)$ & 2.1925 (19) \\
\hline $\mathrm{Ni}(1)-\mathrm{N}\left(1^{i}\right)$ & $2.2952(14)$ & $\mathrm{Ni}(1)-\mathrm{N}(2)$ & $2.0650(2)$ \\
\hline $\mathrm{Ni}(1)-\mathrm{N}(2)$ & $2.0676(13)$ & $\mathrm{Ni}(1)-\mathrm{Cl}(1)$ & $2.3682(9)$ \\
\hline $\mathrm{Ni}(1)-\mathrm{N}\left(2^{\mathrm{i}}\right)$ & $2.0676(13)$ & $\mathrm{Ni}(1)-\mathrm{Cl}\left(1^{i}\right)$ & $2.4372(10)$ \\
\hline $\mathrm{Ni}(1)-\mathrm{Cl}(1)$ & $2.3613(5)$ & $\mathrm{Ni}(1)-\mathrm{Cl}(2)$ & $2.3855(10)$ \\
\hline $\mathrm{Ni}(1)-\mathrm{Cl}\left(1^{i}\right)$ & $2.3613(5)$ & $\mathrm{Ni}(1)-\mathrm{O}(1)$ & $2.1614(18)$ \\
\hline \multicolumn{4}{|c|}{ Bond angles $\left({ }^{\circ}\right)$} \\
\hline$N(1)-N i(1)-N(2)$ & $79.49(5)$ & $N(1)-N i(1)-N(2)$ & $80.75(7)$ \\
\hline$N(1)-N i(1)-N\left(1^{i}\right)$ & 180.0 & $\mathrm{~N}(1)-\mathrm{Ni}(1)-\mathrm{Cl}(2)$ & $96.25(6)$ \\
\hline$N\left(1^{i}\right)-N i(1)-N\left(2^{i}\right)$ & $79.47(5)$ & $\mathrm{N}(2)-\mathrm{Ni}(1)-\mathrm{Cl}(2)$ & $90.77(6)$ \\
\hline$N(1)-N i(1)-N\left(2^{i}\right)$ & $100.53(5)$ & $\mathrm{N}(2)-\mathrm{Ni}(1)-\mathrm{Cl}(1)$ & $93.79(6)$ \\
\hline$N(2)-N i(1)-N\left(2^{i}\right)$ & 180.0 & $\mathrm{~N}(2)-\mathrm{Ni}(1)-\mathrm{Cl}\left(1^{i}\right)$ & $171.89(6)$ \\
\hline$N(2)-N i(1)-N\left(1^{i}\right)$ & $100.53(5)$ & $\mathrm{N}(1)-\mathrm{Ni}(1)-\mathrm{O}(1)$ & $90.58(7)$ \\
\hline $\mathrm{N}(1)-\mathrm{Ni}(1)-\mathrm{Cl}(1)$ & $89.85(4)$ & $\mathrm{N}(2)-\mathrm{Ni}(1)-\mathrm{O}(1)$ & $91.22(7)$ \\
\hline $\mathrm{N}\left(1^{i}\right)-\mathrm{Ni}(1)-\mathrm{Cl}(1)$ & $90.16(3)$ & $\mathrm{O}(1)-\mathrm{Ni}(1)-\mathrm{Cl}(1)$ & $83.74(6)$ \\
\hline $\mathrm{N}(2)-\mathrm{Ni}(1)-\mathrm{Cl}(1)$ & $90.85(4)$ & $\mathrm{O}(1)-\mathrm{Ni}(1)-\mathrm{Cl}(2)$ & $173.11(5)$ \\
\hline $\mathrm{N}\left(2^{i}\right)-\mathrm{Ni}(1)-\mathrm{Cl}(1)$ & $89.15(4)$ & $\mathrm{Cl}(1)-\mathrm{Ni}(1)-\mathrm{Cl}(2)$ & $94.97(3)$ \\
\hline $\mathrm{N}\left(2^{\mathrm{i}}\right)-\mathrm{Ni}(1)-\mathrm{Cl}\left(1^{i}\right)$ & $90.85(4)$ & & \\
\hline $\mathrm{Cl}(1)-\mathrm{Ni}(1)-\mathrm{Cl}\left(1^{i}\right)$ & 180.0 & & \\
\hline
\end{tabular}

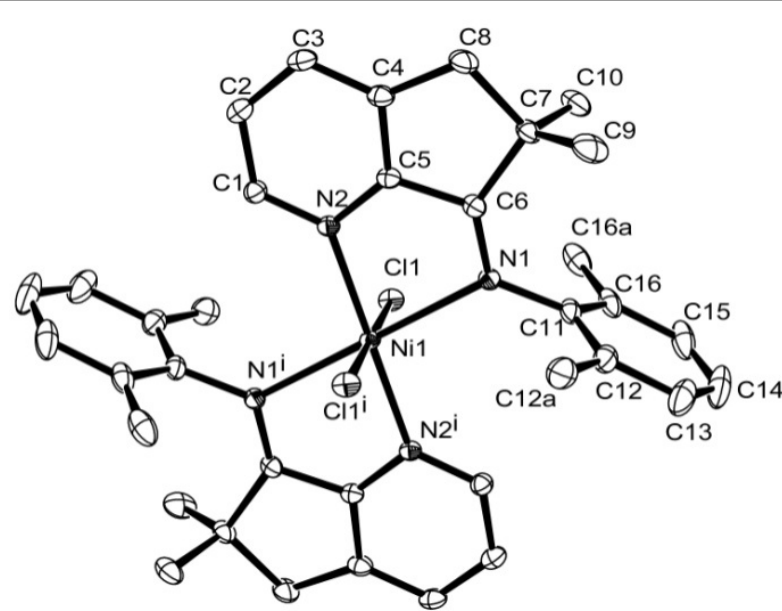

Fig. 1 ORTEP drawing of complex Ni1. Thermal ellipsoids are shown at the $30 \%$ probability level and $\mathrm{H}$ atoms are omitted for clarity.

The structure of $\mathbf{N i 1}$ reveals a mononuclear species in which a nickel atom is coordinated by two $N N$-chelating ligands and two trans-disposed chloride ligands to complete a geometry best described as distorted octahedral. Within each $N N$-chelating ligand there are $N(1)_{\text {imine }}$ and $N(2)_{\text {pyridine }}$ donors which are incorporated into a five-membered chelate ring with the N1-Ni1-N2 bite angle for the bidentate ligand being $79.49(5)^{\circ}$; between bidentate ligands the neighboring pyridine units are disposed mutually trans. The $\mathrm{Ni}-\mathrm{N}_{\text {imine }}(2.2952(14) \AA$ ) bond distance is noticeably longer than $\mathrm{Ni}-\mathrm{N}_{\text {pyridine }}$ bond length (2.0676(13) Å), highlighting the more effective coordination of $\mathrm{N}_{\text {pyridine }}$ with the nickel center; similar trends have been noted in analogous 2-(1-(arylimino)ethyl)-7-arylimino-6,6dimethylcyclopenta[b]pyridines cobalt(II) and chromium(III) chloride complexes previously reported by our group. ${ }^{7,8}$ In addition, the $\mathrm{N}_{\text {imino-aryl }}$ ring is inclined close to perpendicular with respect to the $\mathrm{N} 1, \mathrm{~N} 2, \mathrm{~N} 1^{\mathrm{i}}, \mathrm{N} 2^{\mathrm{i}}$ plane (dihedral angles of $\left.89.50^{\circ}\right)$. No intramolecular contacts of note were apparent.
Unlike Ni1, Ni2 adopts a centrosymmetric chloride-bridged dinuclear structure with only one $N N$-chelating ligand present per nickel center. The geometry around each nickel atom can be described as distorted octahedral, with the nitrogen atoms of the bidentate ligand disposed trans to the bridging chlorides and cis to one terminal chloride and one methanol ligand. The O1-Ni1- $\mathrm{Cl} 2$ angle $\left(173.11(5)^{\circ}\right)$ shows some deviation from the expected $180^{\circ}$. The presence of the O-bound methanol ligand was unexpected and derives from the solvent of crystallization. The $\mathrm{Ni}-\mathrm{N}_{\text {pyridine }}$ bond distance $(2.0650(2) \AA ̊$ ) in $\mathrm{Ni2}$ is comparable with that observed in Ni1 (2.0676(13) $\AA$ ), while the $\mathrm{Ni}-\mathrm{N}_{\text {imine }}$ distance $(2.1925(19) \AA$ ) is slightly shorter than that observed in Ni1 (2.2952(14) $\AA$ ); a similar observation has been highlighted in 8-arylamino-5,6,7-trihydroquinolyl-nickel dichlorides. ${ }^{4 c}$ As with $\mathbf{N i 1}$, the $\mathrm{N}_{\text {imino-aryl ring planes are }}$ inclined towards perpendicular with respect to the plane formed by $\mathrm{N} 1, \mathrm{~N} 2, \mathrm{Cl} 1$, and $\mathrm{Cl}^{i}$ (dihedral angle $=83.61^{\circ}$ ). Similar structural features have been observed elsewhere for nickel complexes bearing either cyclic or acyclic iminopyridine derivatives. ${ }^{5 a, 6 a, 13}$

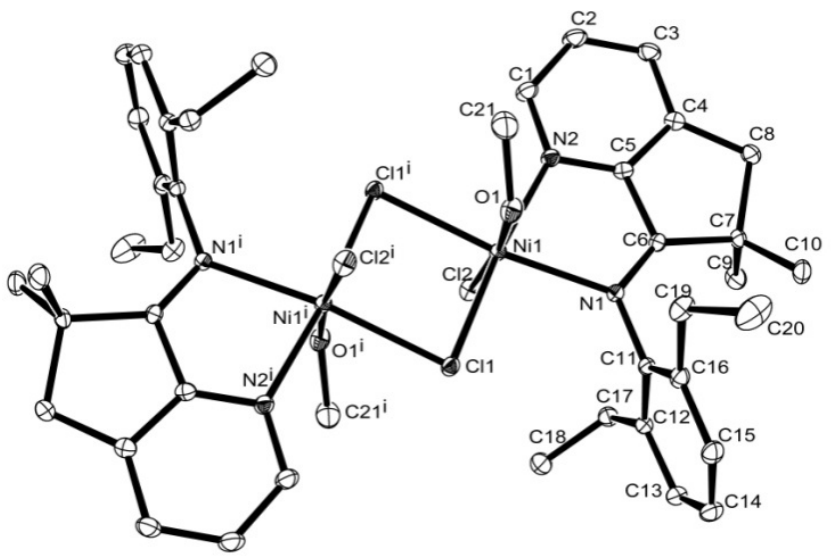

Fig. 2 ORTEP drawing of complex Ni2. Thermal ellipsoids are shown at the $30 \%$ Fig. 2 ORTEP drawing of complex Ni2. Thermal ellipsoi
probability level and $\mathrm{H}$ atoms are omitted for clarity.

Despite using a 1:1 molar ratio of $\mathrm{NiCl}_{2} \cdot 6 \mathrm{H}_{2} \mathrm{O}$ to ligand it was unexpected to observe that both $\mathrm{Ni1}$ and $\mathrm{Ni3}$ adopt bisbidentate structures instead of the predicted mono-bidentate as seen in $\mathbf{N i 2}$ and $\mathbf{N i 4}$. It is uncertain as to the origin of this difference in coordination seen in the solid state, but it may be due to a combination of the relative bulkiness of the orthosubstituents $\left(R^{1}=\right.$ Me for $\mathbf{N i 1}$ vs. $R^{1}=E t$ for $\left.\mathbf{N i 2}\right)$ and ligand/solvent competition for coordination to the metal. In related structures a preference for mono-bidentate coordination has been noted. ${ }^{15}$

\section{Ethylene polymerization: co-catalyst screen}

In order to determine the most efficient co-catalyst for use in the ethylene polymerization studies, $\mathrm{Ni3}$ was initially examined in conjunction with four different alkylaluminium reagents namely methylaluminoxane (MAO), modified methylaluminoxane (MMAO), ethylaluminumsesquichloride (EASC, $\mathrm{Et}_{3} \mathrm{Al}_{2} \mathrm{Cl}_{2}$ ) and diethylaluminium chloride $\left(\mathrm{Et}_{2} \mathrm{AICl}\right)$; the conditions and results are summarized in Table 2 . On the basis 
of the catalytic activities obtained, MAO and MMAO were identified as the most compatible co-catalysts delivering the best overall performances. Hence, all subsequent studies focused on MAO and MMAO (see ESI) as the co-catalysts.

Table 2 Co-catalyst screen using $\mathbf{N i}^{a}$

\begin{tabular}{|c|c|c|c|c|c|c|c|}
\hline Entry & Co-cat. & $\mathrm{Al} / \mathrm{Ni}$ & $\mathrm{PE} / \mathrm{g}$ & Activity $^{b}$ & $T_{\mathrm{m}}{ }^{c} /{ }^{\circ} \mathrm{C}$ & $M_{\mathrm{w}}{ }^{d} / \mathrm{Kg} \cdot \mathrm{mol}^{-1}$ & $M_{\mathrm{w}} / M_{\mathrm{n}}{ }^{d}$ \\
\hline 1 & MAO & 2000 & 10.68 & 4.27 & 77.7 & 0.93 & 1.51 \\
\hline 2 & MMAO & 2000 & 11.65 & 4.66 & 87.0 & 0.83 & 1.51 \\
\hline 3 & $\mathrm{Et}_{2} \mathrm{AlCl}$ & 300 & 1.08 & 0.43 & 99.2 & 1.72 & 1.43 \\
\hline 4 & EASC & 300 & 0.38 & 0.15 & 94.8 & 1.11 & 1.38 \\
\hline
\end{tabular}

${ }^{a}$ Reaction conditions: $5 \mu \mathrm{mol}$ of $\mathrm{Ni3}, 30^{\circ} \mathrm{C}, 30 \mathrm{~min}, 10 \mathrm{~atm}$ of ethylene, $100 \mathrm{~mL}$ total volume of toluene; ${ }^{b} 10^{6} \mathrm{~g}(\mathrm{PE}) \cdot \mathrm{mol}{ }^{-1}(\mathrm{Ni}) \cdot \mathrm{h}^{-1} ;{ }^{c} \mathrm{Determined}^{\mathrm{b}} \mathrm{by} \mathrm{DSC}{ }^{d}$ Determined by GPC.

\section{Using MAO as co-catalyst}

To establish the optimal conditions for the polymerization using a catalyst composed of $\mathbf{N i 3}$ and MAO, the molar ratio of $\mathrm{Al} / \mathrm{Ni}$, reaction temperature and run time were systematically investigated; the results are summarized in Table 3. Firstly, with the run time set at 30 minutes and the temperature at 30 ${ }^{\circ} \mathrm{C}$, the molar ratios of $\mathrm{Al} / \mathrm{Ni}$ were varied between 1750 to 2750 (entries 1-5, Table 3). As the molar ratio was increased, the catalytic activity reached a maximum of $4.68 \times 10^{6}$ $\mathrm{g}(\mathrm{PE}) \cdot \mathrm{mol}^{-1}(\mathrm{Ni}) \cdot \mathrm{h}^{-1}$ with the ratio at 2250 (entry 3, Table 3). Subsequently, the activity gradually decreased as the $\mathrm{Al} / \mathrm{Ni}$ ratio was further increased. The trend in molecular weight of the resultant polymers obtained at different $\mathrm{Al} / \mathrm{Ni}$ ratios is rather irregular, nevertheless the molecular weight distribution $\left(M_{\mathrm{w}} / M_{\mathrm{n}}=1.45-1.51\right)$ is particularly narrow and unimodal as shown by the GPC curves (Fig. 3). Notably, when compared with the polyethylenes obtained using cyclohexylcontaining $D$ (Chart 1 ), ${ }^{9}$ those afforded using Ni3/MAO display narrower polydispersities.

Secondly, with the $\mathrm{Al} / \mathrm{Ni}$ ratio fixed at 2250 and the reaction time at 30 minutes, the temperature was varied between 20 and $60{ }^{\circ} \mathrm{C}$ (entries 3, 6-9, Table 3). The highest activity for $\mathrm{Ni3} / \mathrm{MAO}$ of $5.02 \times 10^{6} \mathrm{~g}(\mathrm{PE}) \cdot \mathrm{mol}^{-1}(\mathrm{Ni}) \cdot \mathrm{h}^{-1}$ was achieved at $20{ }^{\circ} \mathrm{C}$ (entry 6, Table 3 ). Raising the temperature further led to a gradual lowering in activity (entries $7-9$, Table 3) and at $60{ }^{\circ} \mathrm{C}$ a significant drop was observed. This lowering in activity could be attributed to two possible reasons: 1) a reduction in the number of catalytically active species which is most pronounced at $60{ }^{\circ} \mathrm{C}\left(310 \mathrm{~h}^{-1}\right)$, indicative of significant degradation; $4 a, 14$ 2) the solubility of ethylene generally decreases with an increase in temperature. ${ }^{15}$ With regard to the polyethylene obtained, lower temperature leads to higher molecular weight material $\left(1.56 \mathrm{Kg} \cdot \mathrm{mol}^{-1}\right.$ at $\left.20{ }^{\circ} \mathrm{C}\right)$ with a relatively high melt temperature $\left(T_{\mathrm{m}}=71 . \mathrm{o}^{\circ} \mathrm{C}\right)$. When the temperature was increased, the resultant polyethylene displayed lower molecular weight and a lower melt temperature $\left(T_{\mathrm{m}}=59.1-66.4{ }^{\circ} \mathrm{C}\right)$; this molecular weight/temperature correlation is reflected in the GPC curves shown in Fig. 4 and can be attributed to a higher rate of chain termination occurring at elevated temperature as compared to chain propagation (entries 3,6-9, Table 3).4,6

Thirdly, with the $\mathrm{Al} / \mathrm{Ni}$ ratio fixed at 2250 and the temperature at $20^{\circ} \mathrm{C}$, the run time was varied between 5 minutes and two hours. On inspection of the data it is apparent that $\mathrm{Ni3} / \mathrm{MAO}$ required an induction period of 30 minutes following addition of co-catalyst at which point it reaches an optimum catalytic activity of $5.02 \times 10^{6} \mathrm{~g}(\mathrm{PE}) \cdot \mathrm{mol}^{-}$ ${ }^{1}(\mathrm{Ni}) \cdot \mathrm{h}^{-1}$ (entry 6 , Table 3). ${ }^{4,5,6}$ On extending the reaction time beyond this period (entries $13-15$, Table 3 ), the catalytic activities slightly decreased as the active species started to deactivate. ${ }^{16}$ For example, after 1 hour the activity was $4.31 \times$ $10^{6} \mathrm{~g}(\mathrm{PE}) \cdot \mathrm{mol}^{-1}(\mathrm{Ni}) \cdot \mathrm{h}^{-1}$ (entry 14 , Table 3 ), whilst after 2 hours it had reduced to only $2.51 \times 10^{6} \mathrm{~g}(\mathrm{PE}) \cdot \mathrm{mol}^{-1}(\mathrm{Ni}) \cdot \mathrm{h}^{-1}$. Indeed the difference in the number of functional active species between 30 minutes and 2 hours is approximately $892 \mathrm{~h}^{-1}$, highlighting the slow deactivation process occurring (entries 6 and 15 , Table 3 ).

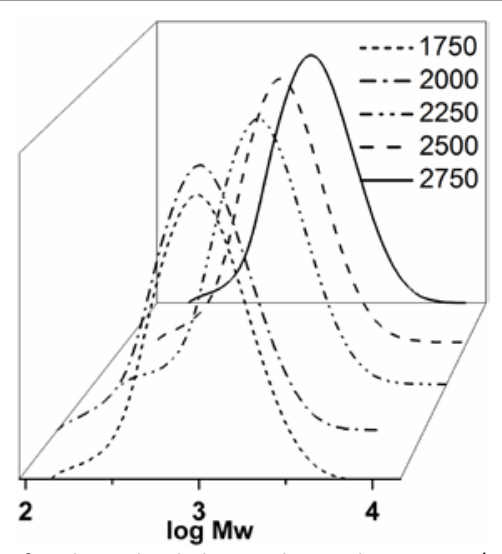

Fig. 3 GPC curves for the polyethylenes obtained using Ni3/MAO with various Fig. 3 GPC curves for the polyeth
Al/Ni ratios (entries $1-5$, Table 3 )

Finally, using the optimized conditions established for $\mathrm{Ni3} / \mathrm{MAO}(\mathrm{Al} / \mathrm{Ni}=2250$, run time $=30$ minutes, temperature $=$ $\left.20{ }^{\circ} \mathrm{C}\right), \mathbf{N i 2}, \mathrm{Ni3}$ and $\mathrm{Ni4}$ were also screened. All precatalysts showed good activities and decreased in the order: Ni3 [2,4,6$\operatorname{tri}(\mathrm{Me})]>\mathrm{Ni1}$ [2,6-di(Me)] > Ni4 [2,6-di(Et)-4-Me] > Ni2 [2,6$\mathrm{di}(\mathrm{Et})]$. In general, the least sterically hindered precatalysts with the most electronically donating groups at the para position (e.g. $\mathrm{CH}_{3}$ instead of $\mathrm{H}$ ) favored high catalytic efficiency. ${ }^{17}$ For instance, $\mathbf{N i 3}$ displayed the highest catalytic activity (entry 6, Table 3 ) due to a combination of the least sterically bulky ortho groups and the positive inductive effect imparted by the methyl group; similar findings have been reported elsewhere. ${ }^{2 b, 17,18}$ 
Table 3 Polymerization of ethylene in the presence of $\mathrm{MAO}^{a}$

\begin{tabular}{|c|c|c|c|c|c|c|c|c|c|c|}
\hline Entry & Pre-cat. & $\mathrm{Al} / \mathrm{Ni}$ & $T /{ }^{\circ} \mathrm{C}$ & $t / \min$ & $\mathrm{PE} / \mathrm{g}$ & Activity $^{b}$ & $T_{\mathrm{m}}{ }^{\mathrm{c}} /{ }^{\circ} \mathrm{C}$ & $M_{\mathrm{w}}{ }^{d} / \mathrm{Kg} \cdot \mathrm{mol}^{-1}$ & $M_{\mathrm{w}} / M_{\mathrm{n}}{ }^{d}$ & $N^{e} / \mathrm{h}^{-1}$ \\
\hline 1 & $\mathrm{Ni3}$ & 1750 & 30 & 30 & 9.68 & 3.87 & 61.5 & 1.22 & 1.46 & 3174 \\
\hline 2 & $\mathrm{Ni3}$ & 2000 & 30 & 30 & 10.68 & 4.27 & 77.7 & 0.93 & 1.51 & 4594 \\
\hline 3 & $\mathrm{Ni3}$ & 2250 & 30 & 30 & 11.70 & 4.68 & 76.0 & 1.24 & 1.47 & 3774 \\
\hline 4 & $\mathrm{Ni3}$ & 2500 & 30 & 30 & 11.31 & 4.52 & 61.8 & 1.14 & 1.45 & 3968 \\
\hline 5 & $\mathrm{Ni3}$ & 2750 & 30 & 30 & 11.20 & 4.48 & 77.1 & 1.24 & 1.45 & 3612 \\
\hline 6 & $\mathrm{Ni3}$ & 2250 & 20 & 30 & 12.55 & 5.02 & 71.2 & 1.56 & 1.63 & 3218 \\
\hline 7 & $\mathrm{Ni3}$ & 2250 & 40 & 30 & 7.05 & 2.82 & 59.1 & 0.81 & 1.47 & 3482 \\
\hline 8 & $\mathrm{Ni3}$ & 2250 & 50 & 30 & 5.68 & 2.27 & 62.1 & 0.72 & 1.42 & 3156 \\
\hline 9 & $\mathrm{Ni3}$ & 2250 & 60 & 30 & 0.55 & 0.22 & 66.4 & 0.71 & 1.43 & 310 \\
\hline 10 & $\mathrm{Ni3}$ & 2250 & 20 & 5 & 0.41 & 0.98 & 61.0 & 1.11 & 1.45 & 888 \\
\hline 11 & $\mathrm{Ni3}$ & 2250 & 20 & 10 & 2.21 & 2.65 & 62.3 & 1.05 & 1.51 & 2526 \\
\hline 12 & $\mathrm{Ni3}$ & 2250 & 20 & 15 & 5.36 & 4.29 & 73.4 & 1.41 & 1.71 & 3040 \\
\hline 13 & $\mathrm{Ni3}$ & 2250 & 20 & 45 & 16.65 & 4.44 & 77.2 & 1.69 & 1.55 & 2587 \\
\hline 14 & $\mathrm{Ni3}$ & 2250 & 20 & 60 & 21.55 & 4.31 & 70.1 & 1.54 & 1.59 & 2798 \\
\hline 15 & $\mathrm{Ni3}$ & 2250 & 20 & 120 & 25.12 & 2.51 & 72.1 & 1.08 & 1.63 & 2326 \\
\hline 16 & Ni1 & 2250 & 20 & 30 & 11.35 & 4.54 & 93.4 & 0.93 & 1.48 & 4882 \\
\hline 17 & $\mathrm{Ni2}$ & 2250 & 20 & 30 & 8.05 & 3.22 & 66.7 & 1.04 & 1.38 & 3096 \\
\hline 18 & $\mathrm{Ni4}$ & 2250 & 20 & 30 & 10.27 & 4.11 & 73.8 & 0.75 & 1.41 & 5478 \\
\hline $19^{f}$ & $\mathrm{Ni3}$ & 2250 & 20 & 30 & 6.04 & 2.41 & 85.7 & 0.99 & 1.44 & 2440 \\
\hline
\end{tabular}

${ }^{a}$ Reaction conditions: $5 \mu \mathrm{mol}$ of $\mathrm{Ni}, 10 \mathrm{~atm}$ of ethylene, $100 \mathrm{~mL}$ total volume of toluene; ${ }^{b} 10^{6} \mathrm{~g}(\mathrm{PE}) \cdot \mathrm{mol}{ }^{-1}(\mathrm{Ni}) \cdot \mathrm{h}^{-1} ;{ }^{c}$ Determined by DSC; ${ }^{d}$ Determined by GPC; ${ }^{e} \mathrm{~N}$ (active species) $=$ the number of polymer molecules / the number of Ni complex molecules; $f$ Conditions: 5 atm of ethylene.

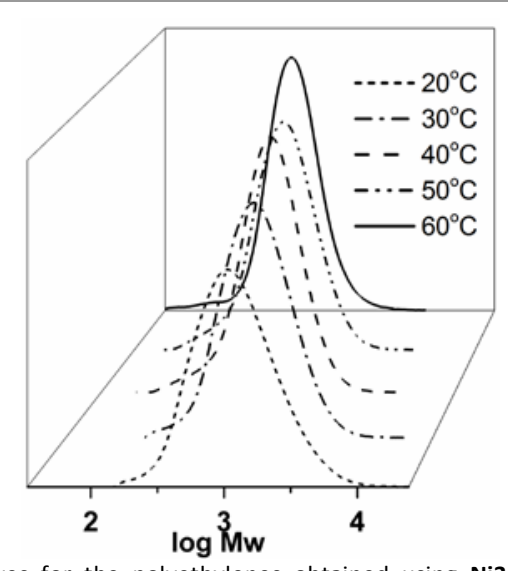

Fig. 4 GPC curves for the polyethylenes obtained using Ni3/MAO system at different temperatures (entries 3, 6-9 in Table 3).

\section{Microstructural properties of the polyethylenes}

The microstructural characteristics of the polyethylenes produced using Ni3/MAO (entry 6, Table 3) have been the subject of a high temperature ${ }^{1} \mathrm{H}$ NMR, ${ }^{13} \mathrm{C}$ NMR and DEPT135 ${ }^{13} \mathrm{C}$ NMR spectroscopic study (recorded in deuterated 1,1,2,2tetrachloroethane at $100{ }^{\circ} \mathrm{C}$ ). In the ${ }^{1} \mathrm{H}$ NMR spectrum (Fig. 5), the peaks centered around 5.90 and $5.00 \mathrm{ppm}$, with a relative peak area ratio of $1: 2$, were unambiguously assigned to the vinyl group $\left(-\mathrm{CH}=\mathrm{CH}_{2}\right)$ located at the end of the polymer chain. ${ }^{19 b, 19 c}$ This assignment is confirmed in the ${ }^{13} \mathrm{C} N M R$ spectrum (Fig. 6) which shows peaks around 114.7 and 139.9 ppm which are characteristic of the carbon atoms belonging to a vinyl end group. In addition to this vinyl group, a multiplet was observed at $5.49 \mathrm{ppm}$ in ${ }^{1} \mathrm{H}$ NMR spectrum attributable to the presence of a vinylene $(-\mathrm{CH}=\mathrm{CH}-)$ group present within the polymer chain. ${ }^{10 \mathrm{~b}}$ He et al. investigated a similar type of polyethylene microstructure that in their case was produced by the copolymerization of ethylene with 1-octene. ${ }^{10 a}$ At this stage, we were not able to specify the exact position of the vinylene group in the polymer chain. However, the integral ratio of all respective double bond protons showed that one of the alkyl chains positioned on either side of the vinylene contained at least two or more carbons. For example, the integral ratio of the $\mathrm{H}_{\mathrm{a}}+\mathrm{H}_{\mathrm{b}}+\mathrm{H}_{\mathrm{c}}+\mathrm{H}_{\mathrm{c}}{ }^{\prime} / \mathrm{H}_{\mathrm{d}}$ protons equates to $5 / 8$ instead of 5/9 illustrating that there is no $-\mathrm{CH}_{3}$ group attached to the $-\mathrm{CH}=\mathrm{CH}-$ group. Furthermore, the ${ }^{13} \mathrm{C}$ NMR spectrum (Fig. 6) reveals peaks around 131 and 124 ppm that could be assigned to two vinylenic carbons with their difference in chemical shift distinguishing the two different chains attached to either side of vinylenic group. In the DEPT135 ${ }^{13} \mathrm{C}$ NMR spectrum (Fig. 7), three positive peaks at 139, 131 and 123 ppm were observed for the $-\mathrm{C}_{\mathrm{b}} \mathrm{H},-\mathrm{C}_{\mathrm{c}} \mathrm{H}$ and $-\mathrm{C}_{\mathrm{c}}{ }^{\prime} \mathrm{H}$ carbons, respectively, and one negative peak at $114 \mathrm{ppm}$ for the $-\mathrm{C}_{\mathrm{a}} \mathrm{H}_{2}$ carbon atom. To the best of our knowledge, Ni1 - Ni4 are the first catalyst systems in ethylene polymerization that produce polyethylenes with double bonds either at the terminal position or within the chain. The mechanistic implications are discussed in detail later (vide infra).

To further confirm the generality of this catalyst family to form related microstructures, samples of polyethylenes obtained using Ni3/MAO at $60{ }^{\circ} \mathrm{C}$ (entry 9, Table 3) and $\mathrm{Ni2} / \mathrm{MAO}$ at $20^{\circ} \mathrm{C}$ (entry 17 , Table 3 ) were characterized by high temperature ${ }^{1} \mathrm{H}$ NMR spectroscopy (Fig. 5). While little difference in chemical shifts was observed in their ${ }^{1} \mathrm{H} N M R$ spectra, the ratio of vinylene groups $(-\mathrm{CH}=\mathrm{CH}-)$ increased at higher temperature: $(-\mathrm{CH}=\mathrm{CH}-) /\left(\mathrm{H}_{2} \mathrm{C}=\mathrm{CH}-\right)=2.2 / 1.0$ with $\mathrm{Ni3} / \mathrm{MAO}$ at $60{ }^{\circ} \mathrm{C}$ and $1.3 / 1.0$ with $\mathrm{Ni2} / \mathrm{MAO}$ at $20{ }^{\circ} \mathrm{C}$ 
(determined by the integration of corresponding peaks). This is likely due to the higher rate of termination at higher temperature and hence enhanced possibilities to generate a vinylene units within the polymer chain. On the other hand, for the sample obtained at $20^{\circ} \mathrm{C}$, the ratio of vinylene to vinyl groups is slightly decreased (Fig. 5). It is worthy of note that such polyethylenes have industrial demand due to their broad applications including in the production of long chain copolymers, functional polymers as well as coating materials. ${ }^{11}$

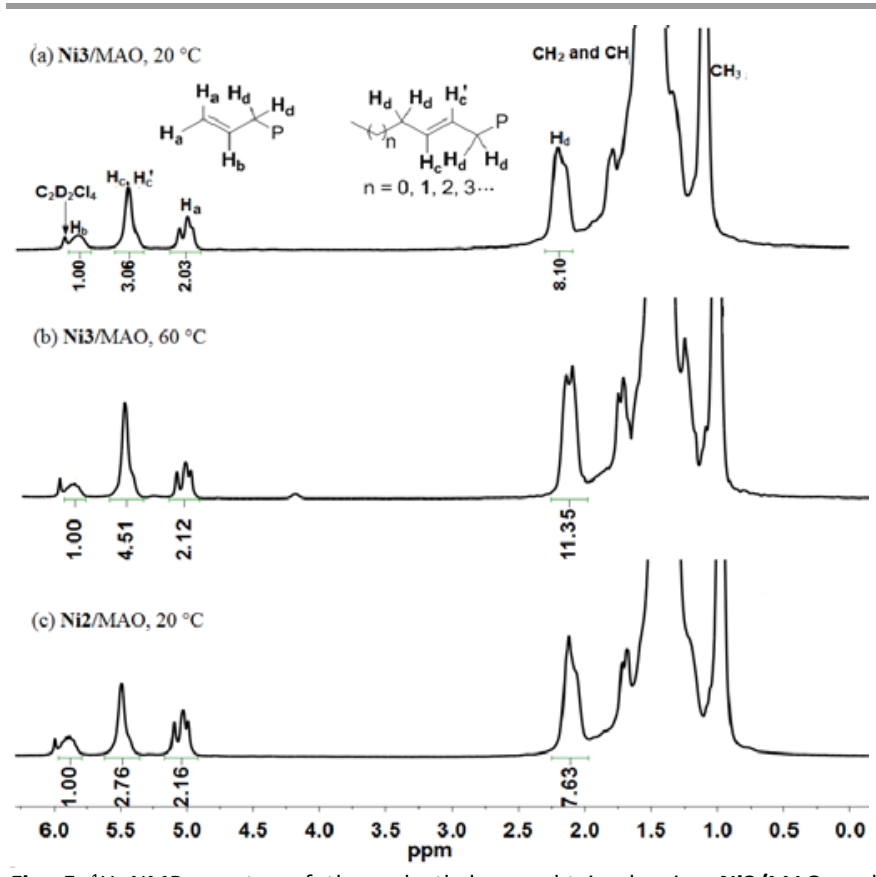

Fig. $5{ }^{1} \mathrm{H}$ NMR spectra of the polyethylenes obtained using Ni3/MAO and $\mathrm{Ni2} / \mathrm{MAO}$ at 20 or $60^{\circ} \mathrm{C}$ (entries 6,9 and 17 , Table 3 )

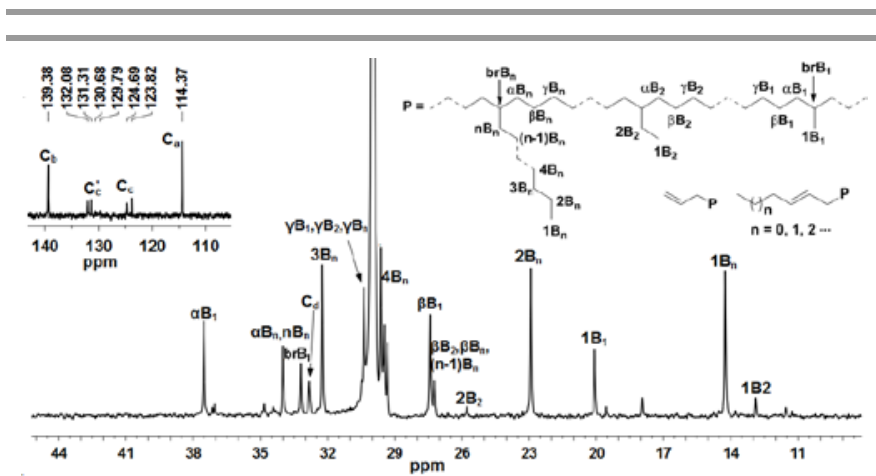

Fig. $6{ }^{13} \mathrm{C}$ NMR spectrum of the polyethylene obtained using $\mathrm{Ni} / \mathrm{MAO}$ at $20{ }^{\circ} \mathrm{C}$ (entry 6, Table 3)

On the basis of the encouraging results reported above using Ni3/MAO, the microstructural properties of the polyethylenes obtained using $\mathrm{Ni3}$ with other co-catalysts (viz. MMAO, $\left.\mathrm{Et}_{2} \mathrm{AlCl}\right)$ were also investigated. A detailed polymerization study using MMAO as co-catalyst has also been conducted (see ESI, Table S1). Ni1 - Ni4/MMAO showed very similar polymerization performances to that observed with MAO and indeed Ni3/MMAO again exhibited the highest activity (up to $4.66 \times 10^{6} \mathrm{~g}(\mathrm{PE}) \cdot \mathrm{mol}^{-1}(\mathrm{Ni}) \cdot \mathrm{h}^{-1}$ ), albeit under slightly different optimized conditions $\left(30^{\circ} \mathrm{C}, 2000 \mathrm{Al} / \mathrm{Ni}\right.$ molar ratio, 30 minutes). For purposes of comparison, samples of polymer obtained using $\mathrm{Ni3} / \mathrm{MMAO}$ and $\mathrm{Ni3} / \mathrm{Et}_{2} \mathrm{AlCl}$ at $30{ }^{\circ} \mathrm{C}$ were also subject to a high temperature ${ }^{1} \mathrm{H}$ NMR spectroscopic study (Fig. 8). The chemical shifts of all the peaks are very similar to the spectrum of the polyethylene obtained using $\mathrm{Ni3} / \mathrm{MAO}$, however there are variations in the relative ratio of vinylene groups present: $(-\mathrm{CH}=\mathrm{CH}-) /\left(\mathrm{H}_{2} \mathrm{C}=\mathrm{CH}-\right)=1.15 / 1.0$ for $\mathrm{Ni3} / \mathrm{MMAO}$ and $0.89 / 1.0$ for $\mathrm{Ni3} / \mathrm{Et}_{2} \mathrm{AlCl}$ (determined by the integration of corresponding peaks).

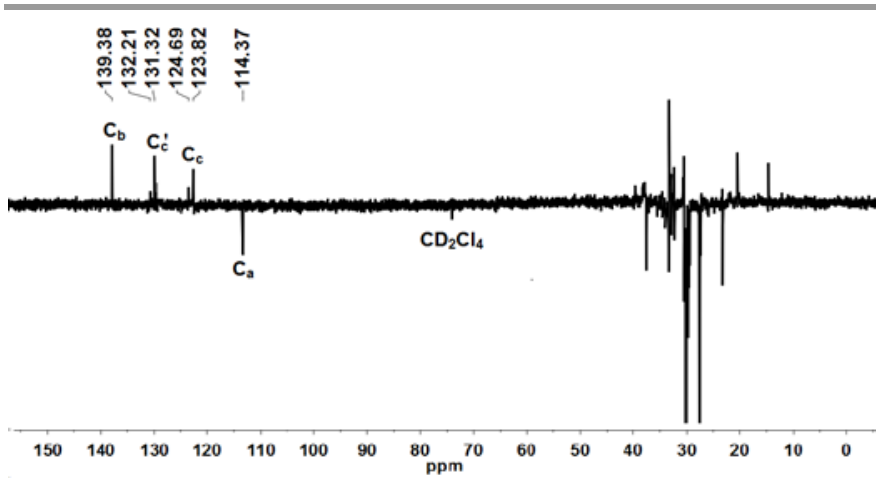

Fig. 7 DEPT $135^{13} \mathrm{C}$ NMR spectrum of the polyethylene obtained using $\mathrm{Ni3} / \mathrm{MAO}$ at $20^{\circ} \mathrm{C}$ (entry 6, Table 3 )

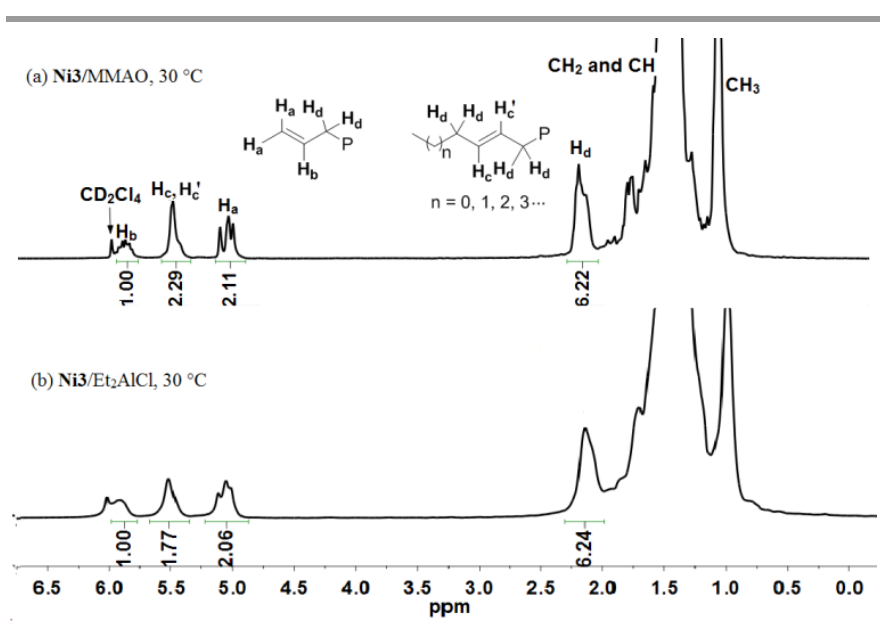

Fig. $8{ }^{1} \mathrm{H}$ NMR spectrum of the polyethylenes obtained using Ni3/MMAO and Ni3/ $\mathrm{Et}_{2} \mathrm{AlCl}$

The microstructure of the polyethylene was further elucidated by a branch number determination based on data acquired from ${ }^{13} \mathrm{C}$ NMR spectra (Fig. 6 and Fig. 9) and interpreted using methods described elsewhere. ${ }^{10 b, 20}$ The polyethylene produced by Ni3/MAO possessed 37 branches per 1000 carbons which included $22.8 \%$ methyl branches, $5.0 \%$ ethyl branches and $72.2 \%$ of long chain branches. In comparison with 8-arylimino-7,7-dimethyl-5,6-dihydroquinolynickel precatalysts (D, Chart 1 ), ${ }^{9}$ a notably higher proportion of long chain branches was obtained, this observation being attributable to the more constrained geometry of the current precatalysts. Moreover, less branches were observed when put alongside literature reports even though they display

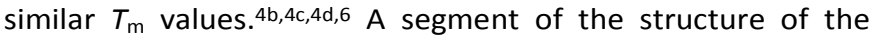
polyethylene obtained is represented in Fig. 6. By contrast, in the polymer obtained using Ni3/MMAO (Fig. 9), a modest reduction in the numbers of branches is observed when compared with the material obtained using Ni3/MAO: 31 
branches per 1000 carbons including 27.2\% methyl branches, $5.4 \%$ ethyl branches and $67.4 \%$ longer chain branches.

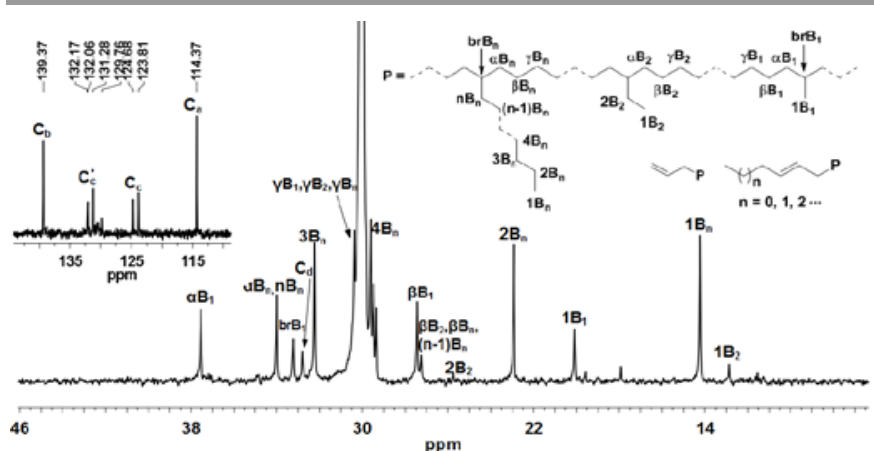

Fig. $9{ }^{13} \mathrm{C}$ NMR spectrum of the polyethylene obtained using $\mathrm{Ni3} / \mathrm{MMAO}$ at $30^{\circ} \mathrm{C}$ (entry 3, Table S1)

\section{Mechanistic implications}

Despite extensive evidence being available from theoretical and some experimental measurements concerning the mechanism of ethylene polymerization, ${ }^{21}$ many questions still remain to be fully answered. For example, i) what relationship between the chelating ligand and the metal determines the polymer properties produced,22 ii) what factors, either electronic, steric or both, are responsible for generating branched polymers, ${ }^{1,4,5,6}$ iii) why do Fe and Co precatalysts tend to give polymers with uniquely vinyl end groups..$^{2 d, 10,23}$ Bearing in mind these questions, ${ }^{1,13,24}$ we postulate a mechanistic pathway that accounts for both the terminal and non-terminal double bonds identified in the polymers found in this study (Scheme 2).

The proposed mechanism comprises three conventional steps namely chain propagation, chain isomerization and chain termination. Following initial coordination of ethylene at the vacant site and insertion of the coordinated ethylene into the $\mathrm{Ni}-\mathrm{R}$ bond, multiple coordination-insertion steps proceed leading to chain growth (propagation step). Chain isomerization is the key step that defines the microstructure with regard to the type of branch and how many branches there are. According to Brookhart's mechanistic studies, ${ }^{21 e, 21 f, 21 g, 21 h, 24 d}$ chain isomerization proceeds by elimination of a $\beta$-agostic hydrogen from the newly formed chain, subsequent rotation of the chain by $180^{\circ}$ around the $\mathrm{M}-$ $\eta^{2}$-olefin bond followed by reattachment of the hydrogen to the terminal carbon atom of the polymer. From our viewpoint we consider that, in addition to $\beta$-agostic hydrogen interactions, $\gamma$-agostic, $\delta$-agostic or greater are likely to take place along the growing chain. Then, following rotation and migration of the hydrogen to the terminal carbon of the polymer chain, methyl, ethyl, propyl and longer chain branches would be formed depending upon which type of agostic interaction initially occurs. ${ }^{19 a, 25}$ In particular, we propose that during chain isomerization, a cyclic intermediate (I, Scheme 2) forms between the agostic hydrogen, metal center and the terminal carbon of the growing chain which is then followed by a rotation of the polymer chain by $180^{\circ}$ to generate intermediate II (Scheme 2), which could be reversible with I. In this scenario, the metal can chain walk on the growing polymer via agostic interactions, rotation and finally transfer of hydrogen to the detached end of the chain; this cycle can then repeat on either side of the growing chain. ${ }^{24 d}$ This phenomenon would be recognized by the presence of an internal vinylene group. At the end, intermediate III (Scheme 2) can have three possible ways to deliver the final microstructure: 1 ) either terminate by $\beta$-hydrogen assistedelimination following pathway $\mathbf{A}$ to generate the internal vinylene, 2 ) repeat the cycle by following pathway $\mathbf{C}$ to afford more branches in the polymer and 3 ) terminate the growing polymer chain with a terminal vinyl group using pathway $\mathbf{B}$ by $\beta$-hydrogen assisted-elimination and again initiate a new chain. Moreover, the low molecular weight of the polymer and the high catalytic activity emphasizes the high rate of $\beta$ elimination and high number of active species as mentioned in Table 3.

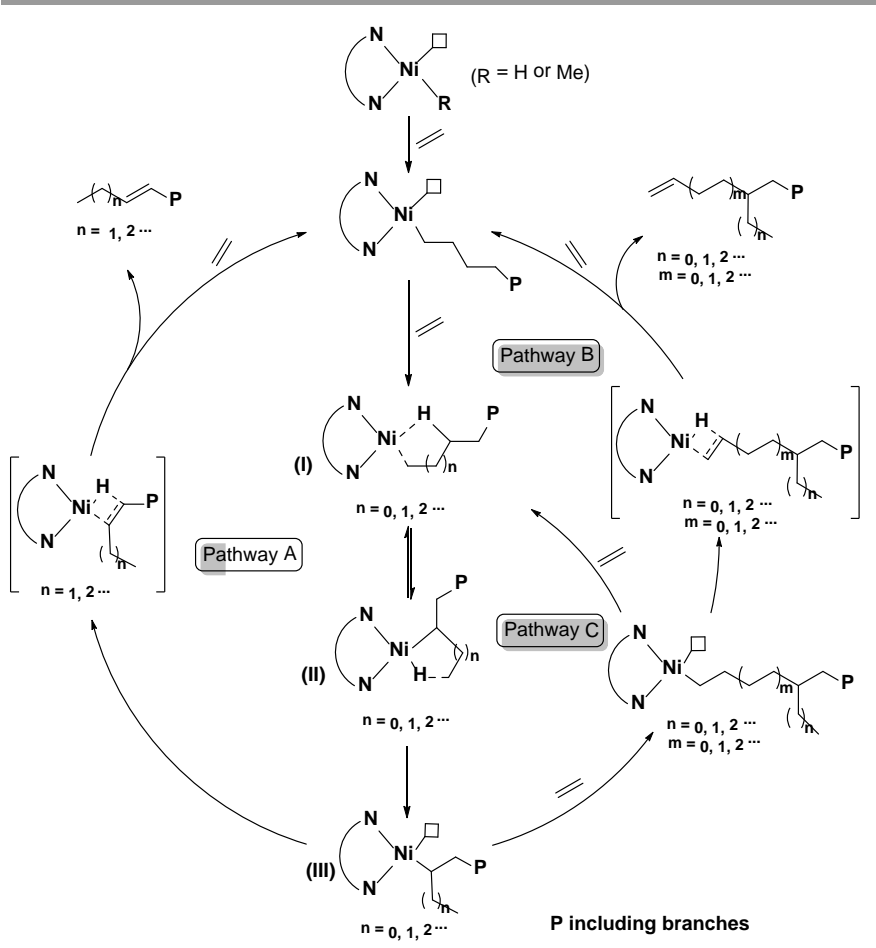

Scheme 2 Proposed mechanism to account for the observed polyethylene microstructure

Though the precise cause for the formation of the vinylene groups is uncertain, we reason that the size of the alkyl ring fused to the pyridine in the imino-cycloalkyl[b]pyridyl ligand system determines the space around the metal center and inturn influences the degree of chain isomerization. ${ }^{7}$ Hence, a smaller size cycloalkyl ring would be expected to enforce a wider spatial arrangement of the chelating ligand when compared to a larger ring; this variation can be expressed in terms of the N-M-N bite angle. For example, cyclopenta[b]pyridyl-cobalt precatalysts ${ }^{7}$ have been shown to display larger bite angles when compared with cyclohexyl[b]pyridyl-cobalt and cyclohepta[b]pyridyl-cobalt precatalysts. ${ }^{17 b, 19 a}$ Likewise, the cyclopenta[b]pyridyl-nickel 
precatalysts developed in this study show larger bite angles, N1-Ni1-N2 $\left(79.49(5)^{\circ}\right.$ in $\mathrm{Ni1}$ and $80.75(7)^{\circ}$ in Ni2), than in the cyclohexyl[b]pyridyl-nickel precatalysts (A, Chart 1 ) (N-Ni-N: $\left.77.60-78.83^{\circ}\right) .{ }^{9}$ This constraining of the $N N$-ligand is likely to create a more accessible metal center leading to rapid ethylene coordination and higher rates of chain isomerization and termination.

\section{Conclusions}

Nickel(II) chloride complexes, Ni1-Ni4, bearing strained $\mathrm{NN}$ chelating imino-cyclopenta[b]pyridines are disclosed, which in the presence of MAO (or MMAO) form unusual unsaturated polyethylenes containing vinyl or vinylene unsaturated functional groups and high levels of long chain branches. All precatalysts showed high activities with $\mathrm{Ni3}$ the standout performer producing polyethylenes of low molecular weight and narrow polydispersities. An alternative mechanism has been proposed to account for the vinylene groups (and alkyl branches) identified within the polyethylenes which could form the basis for future theoretical as well as experimental studies. These types of unsaturated materials could serve as macromers for generating polymers with long chain branching or could be used for further functionalization. This new approach is a cost efficient and potentially industrially applicable route for making materials related to those obtained by the copolymerization of ethylene and an $\alpha$-olefin.

\section{Experimental section}

\section{General procedures}

All manipulations involving air- and/or moisture sensitive compounds were performed in an atmosphere of nitrogen using standard Schlenk techniques. Toluene was refluxed over sodium-benzophenone and distilled under nitrogen before use. Methylaluminoxane (MAO, $1.46 \mathrm{M}$ in toluene) and modified methylaluminoxane (MMAO, $1.93 \mathrm{M}$ in $n$-heptane) were purchased from Akzo Nobel Corp. Diethylaluminium chloride $\left(\mathrm{Et}_{2} \mathrm{AlCl}, 1.17 \mathrm{M}\right.$ in toluene) and ethylaluminium sesquichloride (EASC, $0.87 \mathrm{M}$ in $n$-hexane) were purchased from Acros Chemicals. High purity ethylene was purchased from Beijing Yanshan Petrochemical Co. and used as received. Other reagents were purchased from Aldrich, Acros or local suppliers. NMR spectra were recorded on a Bruker DMX 400 $\mathrm{MHz}$ instrument at ambient temperature using TMS as an internal standard. IR spectra were recorded on a Perkin-Elmer System 2000 FT-IR spectrometer. Elemental analysis was carried out using a Flash EA 1112 microanalyzer. Molecular weights and molecular weight distributions (MWD) of the polyethylenes were determined using a PL-GPC220 GPC/SEC high temperature instrument; three $300 \times 7.5 \mathrm{~mm}$ PL gel $10 \mu$ $\mathrm{m}$ MIXED-BLS columns connected in series were employed. The GPC measurements were undertaken at $150{ }^{\circ} \mathrm{C}$ with a flow rate of $1.0 \mathrm{ml} / \mathrm{min}$ using 1,2,4-trichlorobenzene (TCB) as the eluent. Data collection and handling were carried out using Cirrus GPC Software and Multi Detector Software; data were collected at 1 point per second. The calibrant used for constructing conventional calibration was polystyrene (Calibration KitS-M-10 from the Polymer Labs Company). The true average molecular weights of the polyethylene are generated by inputting the Mark-Houwink constants of the polyethylene; $K$ of 0.727 and $\alpha$ of 40 . Samples were dissolved at a concentration of 0.5 to $2.5 \mathrm{mg} \mathrm{ml}^{-1}$ depending on the molecular weights. The melting points of the polyethylenes were measured from the second scanning run on a PerkinElmer TA-Q2000 differential scanning calorimetry (DSC) analyzer under a nitrogen atmosphere. In the procedure, a sample of about $5.0 \mathrm{mg}$ was heated to $140{ }^{\circ} \mathrm{C}$ at a rate of 20 ${ }^{\circ} \mathrm{C} / \mathrm{min}$ and kept for $2 \mathrm{~min}$ at $140{ }^{\circ} \mathrm{C}$ to remove the thermal history and then cooled at a rate of $20{ }^{\circ} \mathrm{C} / \mathrm{min}$ to $-40{ }^{\circ} \mathrm{C} .{ }^{1} \mathrm{H}$ NMR, ${ }^{13} \mathrm{C}$ NMR and DEPT135 ${ }^{13} \mathrm{C}$ NMR spectra of the polyethylenes were recorded on a Bruker DMX $300 \mathrm{MHz}$ instrument at $100{ }^{\circ} \mathrm{C}$ in deuterated 1,1,2,2-tetrachloroethane with TMS as an internal standard.

Synthesis and characterization of ketone precursors

2-Chloro-cyclopenta[b]pyridin-7-one. 2-Chloro-cyclopentapyridin-7-one was prepared using a method similar to that described in the literature. ${ }^{7}$

2-Chloro-6,6-dimethylcyclopenta[b]pyridin-7-one. 2-Chlorocyclopenta[b]pyridin-7-one (33.6 g, $0.20 \mathrm{~mol}$ ) was added to a suspension of $60 \% \mathrm{NaH}(16.0 \mathrm{~g}, 0.40 \mathrm{~mol})$ in dry THF $(500 \mathrm{~mL})$ at ambient temperature under an atmosphere of nitrogen. After being stirred for $30 \mathrm{~min}$, methyl iodide $(72.0 \mathrm{~g}, 0.50 \mathrm{~mol})$ was slowly added through a pressure equalized dropping funnel and the resulting mixture stirred and heated to $40{ }^{\circ} \mathrm{C}$ for $2 \mathrm{~h}$. After cooling to $0^{\circ} \mathrm{C}$, the mixture was quenched by the slow addition of water and extracted with ethyl acetate $(4 \times$ $150 \mathrm{~mL}$ ). The combined organic layers were washed with water, dried over anhydrous sodium sulfate and filtered. The filtrate was evaporated under reduced pressure and the crude product purified by column chromatography on silica gel using petroleum ether/ethyl acetate $(50 / 1, \mathrm{v} / \mathrm{v})$ as eluent affording 2-chloro-6,6-dimethylcyclopenta[b]pyridin-7-one as a white

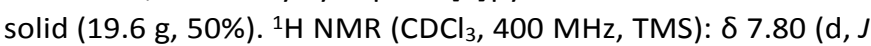
$=8.0 \mathrm{~Hz}, 1 \mathrm{H}), 7.49(\mathrm{~d}, J=8.0 \mathrm{~Hz}, 1 \mathrm{H}), 2.97(\mathrm{~s}, 2 \mathrm{H}), 1.28(\mathrm{~s}, 6 \mathrm{H})$. ${ }^{13} \mathrm{C} \mathrm{NMR}\left(\mathrm{CDCl}_{3}, 100 \mathrm{MHz}, \mathrm{TMS}\right): \delta$ 208.2, 153.3, 153.1, 145.9, 137.7, 128.8, 45.0, 40.1, 25.2. FT-IR (KBr, $\left.\mathrm{cm}^{-1}\right)$ : $2970(\mathrm{w}), 2932$ $(\mathrm{m}), 2867(w), 1720\left(v_{\mathrm{C}=0}, \mathrm{~m}\right), 1579(\mathrm{w}), 1465(\mathrm{~m}), 1433(\mathrm{w})$, $1311(w), 1178(w), 1127(w), 1085(m), 1001(m), 915(w), 873$ $(w), 847(w), 820(m), 731(w), 657(w)$.

6,6-Dimethylcyclopenta[b]pyridin-7-one. A mixture of 2chloro-6,6-dimethylcyclopenta[b]pyridin-7-one $(7.84 \mathrm{~g}, 0.040$ $\mathrm{mol}), \mathrm{NaOH}(1.90 \mathrm{~g}, 0.048 \mathrm{~mol})$ and $10 \% \mathrm{Pd} / \mathrm{C}(0.80 \mathrm{~g})$ in methanol $(80 \mathrm{~mL})$ was stirred under an atmosphere of hydrogen for $8 \mathrm{~h}$ at ambient temperature. The mixture was then filtered and extracted with $\mathrm{CH}_{2} \mathrm{Cl}_{2}(3 \times 50 \mathrm{~mL})$. The organic layers were combined, dried over anhydrous sodium sulfate and concentrated under reduced pressure to afford 6,6dimethylcyclopenta[b]pyridin-7-one as a reddish brown oil $(6.3$ g, 98\%). ${ }^{1} \mathrm{H} \mathrm{NMR}\left(\mathrm{CDCl}_{3}, 400 \mathrm{MHz}, \mathrm{TMS}\right): \delta 8.79(\mathrm{~d}, J=4.0 \mathrm{~Hz}$, $1 \mathrm{H}), 7.87(\mathrm{~d}, J=8.0 \mathrm{~Hz}, 1 \mathrm{H}), 7.50-7.46(\mathrm{~m}, 1 \mathrm{H}), 3.02(\mathrm{~s}, 2 \mathrm{H})$, 1.29 (s, 6H). ${ }^{13} \mathrm{C} \mathrm{NMR}\left(\mathrm{CDCl}_{3}, 100 \mathrm{MHz}, \mathrm{TMS}\right): \delta 210.1,152.7$, 
151.0, 147.1, 135.3, 127.6, 44.4, 40.5, 25.2. FT-IR $\left(\mathrm{KBr}, \mathrm{cm}^{-1}\right)$ : $2963(\mathrm{~m}), 2927(\mathrm{~m}), 2867(\mathrm{w}), 1721\left(v_{\mathrm{c}=0}, \mathrm{~s}\right), 1584(\mathrm{w}), 1469$ (w), $1416(\mathrm{~m}), 1381(w), 1308(w), 1265(w), 1227(w), 1159$ (w), $1103(w), 1043(m), 997(m), 945(w), 862(w), 816(w)$, $778(w), 698(m), 655(w)$.

\section{Synthesis of L1 - L5}

\section{7-(2,6-Dimethylphenylimino)-6,6-dimethylcyclopenta[b]}

pyridine (L1). 2,6-Dimethylaniline $(0.30 \mathrm{~g}, 2.5 \mathrm{mmol})$ was added to a solution containing 6,6dimethylcyclopenta[b]pyridin-7-one $(0.32 \mathrm{~g}, 2.0 \mathrm{mmol})$ and a catalytic amount of $p$-toluenesulfonic acid $(48.0 \mathrm{mg}, 0.24$ $\mathrm{mmol})$ in $o$-dichlorobenzene $(10 \mathrm{~mL})$. The mixture was stirred and heated to reflux for $12 \mathrm{~h}$. On cooling to room temperature the solvent was removed under reduced pressure and the residue purified by chromatography on basic alumina using petroleum ether/ethyl acetate $(100 / 1, v / v)$ as eluent to afford L1 as a yellow solid (0.33 g, 63\%). Mp: $92-94{ }^{\circ} \mathrm{C} .{ }^{1} \mathrm{H}$ NMR $\left(\mathrm{CDCl}_{3}, 400 \mathrm{MHz}, \mathrm{TMS}\right): \delta 8.34(\mathrm{~s}, 1 \mathrm{H}), 7.64(\mathrm{~d}, J=8.0 \mathrm{~Hz}, 1 \mathrm{H})$, $7.15(\mathrm{~s}, 1 \mathrm{H}), 7.00(\mathrm{~d}, J=8.0 \mathrm{~Hz}, 2 \mathrm{H}), 6.88(\mathrm{t}, J=8.0 \mathrm{~Hz}, 1 \mathrm{H}), 2.97$ (s, 2H), 1.97 (s, 6H), $1.46(\mathrm{~s}, 6 \mathrm{H}) .{ }^{13} \mathrm{C} \mathrm{NMR}\left(\mathrm{CDCl}_{3}, 100 \mathrm{MHz}\right.$, TMS): $\delta 174.8,152.8,149.9,149.2,142.1,134.1,127.3,124.7$, 121.9, 42.7, 42.1, 27.8, 18.0. FT-IR (KBr, cm$\left.{ }^{-1}\right)$ : $3012(\mathrm{w}), 2926$ $(m), 2857(w), 1680\left(v_{C=N}, s\right), 1591(w), 1465(w), 1438(m)$, $1411(\mathrm{~m}), 1375(w), 1295(w), 1260(w), 1234(w), 1190(w)$ $1088(w), 1050(m), 1013(w), 949(m), 918(w), 809(m), 765$ (s), $677(\mathrm{~m})$. Anal. Calcd for $\mathrm{C}_{18} \mathrm{H}_{20} \mathrm{~N}_{2}: \mathrm{C}, 81.78 ; \mathrm{H}, 7.63 ; \mathrm{N}$, 10.60. Found: C, 81.88; $\mathrm{H}, 7.57 ; \mathrm{N}, 10.34$.

\section{7-(2,6-Diethylphenylimino)-6,6-dimethylcyclopenta[b]}

pyridine (L2). Using the same procedure as described for the synthesis of L1, $\mathbf{L 2}$ was obtained as a yellow oil $(0.36 \mathrm{~g}, 62 \%)$. ${ }^{1} \mathrm{H} \mathrm{NMR}\left(\mathrm{CDCl}_{3}, 400 \mathrm{MHz}, \mathrm{TMS}\right): \delta 8.33(\mathrm{~s}, 1 \mathrm{H}), 7.64(\mathrm{~d}, J=8.0$ $\mathrm{Hz}, 1 \mathrm{H}), 7.13(\mathrm{t}, J=6.0 \mathrm{~Hz}, 1 \mathrm{H}), 7.04(\mathrm{~d}, J=8.0 \mathrm{~Hz}, 2 \mathrm{H}), 6.97(\mathrm{t}, J$ $=2.7 \mathrm{~Hz}, 1 \mathrm{H}), 2.97(\mathrm{~s}, 2 \mathrm{H}), 2.44-2.35(\mathrm{~m}, 2 \mathrm{H}), 2.33-2.26(\mathrm{~m}$, $2 \mathrm{H}), 1.46(\mathrm{~s}, 6 \mathrm{H}), 1.03(\mathrm{t}, \mathrm{J}=8.0 \mathrm{~Hz}, 6 \mathrm{H}) .{ }^{13} \mathrm{C} \mathrm{NMR}\left(\mathrm{CDCl}_{3}, 100\right.$ $\mathrm{MHz}, \mathrm{TMS}): \delta 174.4,152.8,149.8,148.4,142.3,134.1,130.5$, 125.3, 124.7, 122.1, 42.7, 42.1, 27.7, 24.6, 13.6. FT-IR (KBr, $\left.\mathrm{cm}^{-1}\right)$ : $2960(\mathrm{~s}), 2927(\mathrm{~m}), 2866(\mathrm{w}), 1672\left(v_{\mathrm{C}=\mathrm{N}}, \mathrm{s}\right), 1591(\mathrm{w})$, $1574(w), 1445(m), 1413(m), 1358(w), 1296(w), 1260(w)$, $1157(w), 1102(w), 1050(m), 1015(w), 871(w), 832(w), 804$ (m), 759 (s), 718 (w), 676 (w). Anal. Calcd for $\mathrm{C}_{20} \mathrm{H}_{24} \mathrm{~N}_{2}$ : C, 82.15; H, 8.27; N, 9.58. Found: C, 82.19; H, 8.31; N, 9.33.

\section{7-(2,4,6-Trimethylphenylimino)-6,6-dimethylcyclopenta[b]} pyridine (L3). Using the same procedure as described for the synthesis of L1, L3 was obtained as a yellow solid (0.35 g, 63\%). Mp: $99-101{ }^{\circ} \mathrm{C} .{ }^{1} \mathrm{H}$ NMR $\left(\mathrm{CDCl}_{3}, 400 \mathrm{MHz}, \mathrm{TMS}\right): \delta 8.37$ (d, $J=$ $6.0 \mathrm{~Hz}, 1 \mathrm{H}), 7.64(\mathrm{~d}, J=8.0 \mathrm{~Hz}, 1 \mathrm{H}), 7.14(\mathrm{t}, J=4.0 \mathrm{~Hz}, 1 \mathrm{H}), 6.82$ (s, 2H), $2.97(\mathrm{~s}, 2 \mathrm{H}), 2.28(\mathrm{~s}, 3 \mathrm{H}), 1.94(\mathrm{~s}, 6 \mathrm{H}), 1.45(\mathrm{~s}, 6 \mathrm{H}) .{ }^{13} \mathrm{C}$ NMR $\left(\mathrm{CDCl}_{3}, 100 \mathrm{MHz}, \mathrm{TMS}\right): \delta 174.8,152.8,149.9,146.6$, 142.1, 134.1, 130.8, 128.0, 124.6, 124.5, 42.7, 42.1, 27.9, 20.9, 17.9. FT-IR (KBr, cm $\left.{ }^{-1}\right): 2954(\mathrm{~s}), 2915(\mathrm{~m}), 2852(\mathrm{w}), 1677\left(v_{\mathrm{C}=\mathrm{N}}\right.$, s), $1574(w), 1465(s), 1435(m), 1412(w), 1372(w), 1296(w)$, $1259(w), 1239(w), 1187(w), 1166(w), 1053(m), 1012(w)$, $944(w), 846(w), 810(m), 752(w), 676(w)$. Anal. Calcd for $\mathrm{C}_{19} \mathrm{H}_{22} \mathrm{~N}_{2}: \mathrm{C}, 81.97 ; \mathrm{H}, 7.97 ; \mathrm{N}, 10.06$. Found: C, 81.74; H, 8.01; $\mathrm{N}, 9.70$.
7-(2,6-Diethyl-4-methylphenylimino)-6,6-dimethylcyclopenta [b]pyridine (L4). Using the same procedure as described for the synthesis of L1, L4 was obtained as a yellow solid $(0.40 \mathrm{~g}$, 65\%). Mp: $154-156{ }^{\circ} \mathrm{C} .{ }^{1} \mathrm{H} ~ \mathrm{NMR}\left(\mathrm{CDCl}_{3}, 400 \mathrm{MHz}, \mathrm{TMS}\right): \delta 8.30$ (d, $J=4.0 \mathrm{~Hz}, 1 \mathrm{H}), 7.63(\mathrm{~d}, J=8.0 \mathrm{~Hz}, 1 \mathrm{H}), 7.12(\mathrm{t}, J=6.0 \mathrm{~Hz}$, $1 \mathrm{H}), 6.85(\mathrm{~s}, 2 \mathrm{H}), 2.96(\mathrm{~s}, 2 \mathrm{H}), 2.40-2.21(\mathrm{~m}, 7 \mathrm{H}), 1.45(\mathrm{~s}, 6 \mathrm{H})$, $1.01(\mathrm{t}, J=5.3 \mathrm{~Hz}, 6 \mathrm{H}) .{ }^{13} \mathrm{C} \mathrm{NMR}\left(\mathrm{CDCl}_{3}, 100 \mathrm{MHz}, \mathrm{TMS}\right): \delta$ $174.4,152.8,149.7,145.7,142.2,134.0,131.0,130.3,126.1$, 124.5, 42.7, 42.1, 27.7, 26.9, 24.6, 21.1, 13.7. FT-IR ( $\left.\mathrm{KBr}, \mathrm{cm}^{-1}\right)$ : $2960(\mathrm{~s}), 2925(\mathrm{~m}), 2864(\mathrm{w}), 1672\left(v_{\mathrm{C}=\mathrm{N}}, \mathrm{s}\right), 1574(\mathrm{~m}), 1458(\mathrm{~s})$, $1414(m), 1296(w), 1260(w), 1227(w), 1161(w), 1140(w)$, $1050(w), 1015(w), 856(m), 804(m), 771(w), 676(w)$. Anal. Calcd for $\mathrm{C}_{21} \mathrm{H}_{26} \mathrm{~N}_{2}$ : C, 82.31; H, 8.55; N, 9.14. Found: C, 82.30; $\mathrm{H}, 8.33 ; \mathrm{N}, 9.02$.

\section{7-(2,6-Diisopropylphenylimino)-6,6-dimethylcyclopenta[b]}

pyridine (L5). Using the same procedure as described for the synthesis of L1, $\mathbf{L} \mathbf{5}$ was obtained as a yellow solid $(0.43 \mathrm{~g}, 64 \%)$. Mp: $52-54{ }^{\circ} \mathrm{C} .{ }^{1} \mathrm{H}$ NMR $\left(\mathrm{CDCl}_{3}, 400 \mathrm{MHz}, \mathrm{TMS}\right): \delta 8.34(\mathrm{~s}, 1 \mathrm{H})$, $7.65(\mathrm{~d}, J=8.0 \mathrm{~Hz}, 1 \mathrm{H}), 7.15-7.06(\mathrm{~m}, 4 \mathrm{H}), 3.00(\mathrm{~s}, 2 \mathrm{H}), 2.84-$ $2.78(\mathrm{~m}, 2 \mathrm{H}), 1.47(\mathrm{~s}, 6 \mathrm{H}), 1.18(\mathrm{~d}, J=8.0 \mathrm{~Hz}, 6 \mathrm{H}), 0.91(\mathrm{~d}, J=$ $8.0 \mathrm{~Hz}, 6 \mathrm{H}) .{ }^{13} \mathrm{C} \mathrm{NMR}\left(\mathrm{CDCl}_{3}, 100 \mathrm{MHz}, \mathrm{TMS}\right): \delta 174.4,152.8$, $149.6,147.5,142.4,134.9,134.1,124.6,122.3,122.2,42.7$, 42.1, 28.1, 27.6, 22.9, 22.8. FT-IR ( $\left.\mathrm{KBr}, \mathrm{cm}^{-1}\right): 2955$ (s), 2925 $(\mathrm{m}), 2863(\mathrm{w}), 1678\left(v_{\mathrm{C}=\mathrm{N}}, \mathrm{s}\right), 1573(\mathrm{w}), 1456(\mathrm{~m}), 1431(\mathrm{~s}), 1411$ (m), $1359(w), 1294(w), 1179(w), 1155(w), 1103(w), 1044$ (w), $932(w), 830(\mathrm{~m}), 803(w), 757(\mathrm{~s}), 711(w), 675(w)$. Anal. Calcd for $\mathrm{C}_{22} \mathrm{H}_{28} \mathrm{~N}_{2}$ : C, 82.45; H, 8.81; N, 8.74. Found: C, 82.40; $\mathrm{H}, 8.72 ; \mathrm{N}, 8.53$.

\section{Syntheses of $\mathrm{Ni1}-\mathrm{Ni} 4$}

\section{7-(2,6-Dimethylphenylimino)-6,6-dimethylcyclopenta[b]}

pyridyl-nickel chloride ( $\mathrm{Ni1}) . \mathrm{NiCl}_{2} \cdot 6 \mathrm{H}_{2} \mathrm{O}(0.064 \mathrm{~g}, 0.27 \mathrm{mmol})$ was dissolved in ethanol $(2 \mathrm{~mL})$ and added to a solution of $\mathbf{L 1}$ (0.079 g, $0.3 \mathrm{mmol})$ in $\mathrm{CH}_{2} \mathrm{Cl}_{2}(10 \mathrm{~mL})$. The mixture was stirred at room temperature for $12 \mathrm{~h}$ and then diethyl ether introduced to precipitate the complex. The precipitate was collected by filtration, washed with diethyl ether and dried under reduced pressure to give $\mathbf{N i 1}$ as a yellow powder $(0.060$ g, 61\%). FT-IR (KBr, cm $\left.{ }^{-1}\right)$ : 3007 (w), $2971(w), 2920(w), 2873$ $(w), 1639\left(v_{\mathrm{C}=N}, s\right), 1606(\mathrm{~m}), 1449(\mathrm{~m}), 1433(\mathrm{w}), 1386(\mathrm{w})$, $1332(w), 1301(w), 1210(w), 1190(s), 1170(w), 1222(w)$, $1099(w), 1060(w), 1021(w), 884(m), 805(s), 781(w), 683$ (w), 657 (w). Anal. Calcd for $\mathrm{C}_{36} \mathrm{H}_{40} \mathrm{~N}_{4} \mathrm{NiCl}_{2}: \mathrm{C}, 65.68 ; \mathrm{H}, 6.12 ; \mathrm{N}$, 8.51. Found: $\mathrm{C}, 65.40 ; \mathrm{H}, 6.02 ; \mathrm{N}$, 8.53. MS-ESI: calcd for $\mathrm{C}_{36} \mathrm{H}_{40} \mathrm{~N}_{4} \mathrm{NiCl}_{2} \mathrm{~m} / z$ 656.20, found $\mathrm{m} / z 621.23(\mathrm{M}-\mathrm{Cl})^{+}$.

7-(2,6-Diethylphenylimino)-6,6-dimethylcyclopenta[b]pyridylnickel chloride (Ni2). Using a procedure similar to that described for Ni1, Ni2 was isolated as a yellow powder $(0.098$ g, 87\%). FT-IR (KBr, cm$\left.{ }^{-1}\right)$ : $2964(w), 2933(w), 2875(w), 1635$ $\left(v_{\mathrm{C}=\mathrm{N}}, \mathrm{s}\right), 1606(\mathrm{~m}), 1443(\mathrm{~s}), 1366(\mathrm{w}), 1329(\mathrm{~m}), 1298(\mathrm{w}), 1234$ (w), 1169 (s), $1112(w), 1058(w), 1019$ (w), $860(w), 798$ (s), $773(\mathrm{~m}), 682(\mathrm{w}), 654(\mathrm{w})$. Anal. Calcd for $\mathrm{C}_{40} \mathrm{H}_{48} \mathrm{~N}_{4} \mathrm{Ni}_{2} \mathrm{Cl}_{4}$ : C, 56.92; $\mathrm{H}, 5.73 ; \mathrm{N}, 6.64$. Found: $\mathrm{C}, 56.48 ; \mathrm{H}, 6.01 ; \mathrm{N}, 6.33$. MSESI: calcd for $\mathrm{C}_{36} \mathrm{H}_{40} \mathrm{~N}_{4} \mathrm{NiCl}_{2} \mathrm{~m} / z$ 840.14, found $\mathrm{m} / \mathrm{z} 805.17$ $(\mathrm{M}-\mathrm{Cl})^{+}$.

7-(2,4,6-Trimethylphenylimino)-6,6-dimethylcyclopenta[b] pyridyl-nickel chloride (Ni3). Using a procedure similar to that 
described for Ni1, Ni3 was isolated as a yellow powder $(0.088$ g, 86\%). FT-IR (KBr, cm ${ }^{-1}$ ): 2988 (w), 2960 (w), 2918 (w), 2863 $(w), 1638\left(v_{c=N}, s\right), 1606(m), 1457(m), 1384(w), 1333(w)$, $1308(w), 1195$ (w), $1212(w), 1184(w), 1174(w), 1140(m)$, $1055(w), 1018(w), 880(w), 852(m), 803(s), 753(w), 682(w)$, 655 (w). Anal. Calcd for $\mathrm{C}_{38} \mathrm{H}_{44} \mathrm{~N}_{4} \mathrm{NiCl}_{2}$ : C, 66.49; $\mathrm{H}, 6.46 ; \mathrm{N}$, 8.16. Found: $\mathrm{C}, 64.49 ; \mathrm{H}, 6.60 ; \mathrm{N}, 8.57$. MS-ESI: calcd for $\mathrm{C}_{38} \mathrm{H}_{44} \mathrm{~N}_{4} \mathrm{NiCl}_{2} \mathrm{~m} / \mathrm{z}$ 684.22, found $\mathrm{m} / \mathrm{z} 649.26(\mathrm{M}-\mathrm{Cl})^{+}$.

Table 4 Crystal data and structure refinement for $\mathbf{N i 1}$ and $\mathbf{N i 2} \cdot 2 \mathrm{CH}_{3} \mathrm{OH}$

\begin{tabular}{|c|c|c|}
\hline & $\mathrm{Ni1}$ & $\mathrm{Ni2} \cdot 2 \mathrm{CH}_{3} \mathrm{OH}$ \\
\hline Empirical formula & $\mathrm{C}_{36} \mathrm{H}_{40} \mathrm{Cl}_{2} \mathrm{~N}_{4} \mathrm{Ni}$ & $\mathrm{C}_{42} \mathrm{H}_{54} \mathrm{Cl}_{4} \mathrm{~N}_{4} \mathrm{Ni}_{2} \mathrm{O}_{2}$ \\
\hline Formula weight & 658.31 & 906.07 \\
\hline Temperature/K & $173(2)$ & $173(2)$ \\
\hline Wavelength/ $\AA$ & 0.71073 & 0.71073 \\
\hline Crystal system & Monoclinic & Triclinic \\
\hline space group & $P 2(1) / n$ & $P-1$ \\
\hline$a / \AA ̊$ & $9.0742(18)$ & $9.7278(19)$ \\
\hline$b / \AA ̊$ & $14.496(3)$ & $10.550(2)$ \\
\hline$c / \AA ̊$ & $12.391(3)$ & $11.522(2)$ \\
\hline Alpha/ ${ }^{\circ}$ & 90 & $91.22(3)$ \\
\hline Beta $/^{\circ}$ & $98.03(3)$ & $109.68(3)$ \\
\hline Gamma $/^{\circ}$ & 90 & $108.69(3)$ \\
\hline Volume $/ \AA^{3}$ & $1613.9(6)$ & 1043.6(3) \\
\hline Z & 2 & 1 \\
\hline$D_{\text {calcd }} /\left(\mathrm{g} \mathrm{cm}^{-3}\right)$ & 1.355 & 1.442 \\
\hline$\mu / \mathrm{mm}^{-1}$ & 0.798 & 1.199 \\
\hline$F(000)$ & 693.5 & 474 \\
\hline Crystal size /mm & $0.199 \times 0.106 \times 0.091$ & $0.28 \times 0.24 \times 0.18$ \\
\hline$\vartheta$ range $/{ }^{\circ} \mathrm{C}$ & $5.94-55$ & $90-27.51$ \\
\hline \multirow[t]{3}{*}{ Limiting indices } & $-10 \leq h \leq 11$ & $-12 \leq h \leq 12$ \\
\hline & $-18 \leq k \leq 18$ & $-13 \leq k \leq 13$ \\
\hline & $-16 \leq \mathrm{I} \leq 12$ & $-14 \leq \mathrm{I} \leq 14$ \\
\hline No. of rflns collected & 10742 & 13422 \\
\hline No. unique rflns $[R$ (int)] & $8887(0.0303)$ & $4730(0.0285)$ \\
\hline Completeness to $\vartheta$ & $99.1 \%$ & $98.6 \%$ \\
\hline Data/restraints/parameters & $3674 / 0 / 199$ & $4730 / 0 / 249$ \\
\hline Goodness of fit on $F^{2}$ & 1.039 & 1.262 \\
\hline \multirow[t]{2}{*}{ Final $R$ indices $[1>2 \Sigma(I)]$} & $R_{1}=0.0358$ & $\mathrm{R}_{1}=0.0336$ \\
\hline & $w R_{2}=0.0854$ & $w R_{2}=0.1043$ \\
\hline \multirow[t]{2}{*}{$R$ indices (all data) } & $R_{1}=0.0373$ & $\mathrm{R}_{1}=0.0384$ \\
\hline & $\mathrm{w} R_{2}=0.0865$ & $w R_{2}=0.1231$ \\
\hline $\begin{array}{c}\text { Largest diff. peak and } \\
\text { hole }\left(e \AA^{-3}\right)\end{array}$ & 0.43 and -0.27 & 0.654 and -0.899 \\
\hline
\end{tabular}

7-(2,6-Diethyl-4-methylphenylimino)-6,6-dimethylcyclopenta [b]pyridyl-nickel chloride ( $\mathrm{Ni4})$. Using a similar procedure to that described for $\mathbf{N i 1}, \mathbf{N i 4}$ was isolated as yellow powder (0.069 g, 59\%). FT-IR (KBr, cm-1): 2963 (w), 2932 (w), $2870(w)$, $1636\left(v_{\mathrm{C}=\mathrm{N}}, \mathrm{s}\right), 1608(\mathrm{~m}), 1457(\mathrm{~s}), 1382(\mathrm{w}), 1332(\mathrm{w}), 1210(\mathrm{w})$, 1188 (w), 1166 (w), 1136 (w), 1056 (w), 1023 (w), 860 (m), 799 (s), 751 (w), $660(w)$. Anal. Calcd for $\mathrm{C}_{42} \mathrm{H}_{52} \mathrm{~N}_{4} \mathrm{Ni}_{2} \mathrm{Cl}_{4}: \mathrm{C}, 57.84 ; \mathrm{H}$, 6.01; N, 6.42. Found: $\mathrm{C}, 57.71 ; \mathrm{H}, 6.10 ; \mathrm{N}, 6.16$. MS-ESI: calcd for $\mathrm{C}_{42} \mathrm{H}_{52} \mathrm{~N}_{4} \mathrm{Ni}_{2} \mathrm{Cl}_{4} \mathrm{~m} / z$ 868.16, found $\mathrm{m} / \mathrm{z} 833.19(\mathrm{M}-\mathrm{Cl})^{+}$.

\section{X-ray crystallographic studies}

Single crystals of $\mathbf{N i 1}$ and $\mathbf{N i 2}$ suitable for the X-ray diffraction determination were obtained by slow diffusion of diethyl ether into a methanol solution of the complex at room temperature. The X-ray studies were carried out on a Rigaku Saturn724 + CCD with graphite-monochromatic Mo- $K_{\alpha}$ radiation $(\lambda=$ $0.71073 \AA$ A) at 173 (2) K; cell parameters were obtained by global refinement of the positions of all collected reflections. Intensities were corrected for Lorentz and polarization effects and empirical absorption. The structures were solved by direct methods and refined by full-matrix least squares on $F^{2}$. All hydrogen atoms were placed in calculated positions. Structure solution and refinement were performed by using the SHELXL97 package. ${ }^{26}$ Details of the X-ray structure determinations and refinements are provided in Table 4.

\section{Acknowledgements}

This work was supported by National Natural Science Foundation of China (Nos. U1362204, 21473160, 21374123 and 51373176). GAS is grateful to the Chinese Academy of Sciences for a Visiting Scientist Fellowship.

\section{References}

1 (a) L. K. Johnson, C. M. Killian and M. Brookhart, J. Am. Chem. Soc., 1995, 117, 6414; (b) W.-H. Sun, Adv. Polym. Sci., 2013, 258, 163; (c) R. Gao, W.-H. Sun and C. Redshaw, Catal. Sci. Technol., 2013, 3, 1172; (d) S. Wang and W.-H. Sun, C. Redshaw, J. Organomet. Chem., 2014, 751, 717; (e) C. Bianchini, G. Giambastiani, L. Luconi and A. Meli, Coord. Chem. Rev., 2010, 254, 431; (f) S. D. Ittel and L. K. Johnson, Chem. Rev., 2000, 100, 1169.

2 (a) F. Huang, Q. Xing, T. Liang, Z. Flisak, B. Ye, X. Hu, W. Yang and W.-H. Sun, Dalton Trans., 2014, 43, 16818; (b) Q. Xing, T. Zhao, Y. Qiao, L. Wang, C. Redshaw and W.-H. Sun, RSC Adv., 2013, 3, 26184; (c) S. Wang, W. Zhao, X. Hao, B. Li, C. Redshaw, Y. Li and W.-H. Sun, J. Organomet. Chem., 2013, 731, 78; (d) Q. Xing, T. Zhao, S. Du, W. Yang, T. Liang, C. Redshaw and W.-H. Sun, Organometallics, 2014, 33, 1382.

3 (a) G. J. P. Britovsek, V. C. Gibson and D. F. Wass, Angew. Chem. Int. Ed., 1999, 38, 428; (b) V. C. Gibson and S. K. Spitzmesser, Chem. Rev., 2003, 103, 283; (c) V. C. Gibson, C. Redshaw and G. A. Solan, Chem. Rev., 2007, 107, 1745; (d) W.-H. Sun, S. Zhang and W. Zuo, C. R. Chim., 2008, 11, 307; (e) S. Jie, W.-H. Sun and T. Xiao, Chin. J. Polym. Sci., 2010, 28, 299; (f) V. C. Gibson and G. A. Solan, in Catalysis without Precious Metals, ed. M. Bullock, Wiley-VCH, Weinheim, 2010, pp. 111; (g) V. C. Gibson and G. A. Solan, Top. Organomet. Chem., 2009, 26, 107.

4 (a) J. Yu, Y. Zeng, W. Huang, X. Hao and W.-H. Sun, Dalton Trans., 2011, 40, 8436; (b) X. Hou, Z. Cai, X. Chen, L. Wang, C. Redshaw and W.-H. Sun, Dalton Trans., 2012, 41, 1617; (c) L. Zhang, X. Hao, W.-H. Sun and C. Redshaw, ACS Catal., 2011, 1, 1213; (d) Z. Sun, E. Yue, M. Qu, I. V. Oleynik, I. I. Oleynik, K. $\mathrm{Li}$, T. Liang, W. Zhang and W.-H. Sun, Inorg. Chem. Front., 2015, 2, 223.

5 (a) J. Yu, X. Hu, Y. Zeng, L. Zhang, C. Ni, X. Hao and W.-H. Sun, New J. Chem., 2011, 35, 178; (b) W. Chai, J. Yu, L. Wang, X. Hu, C. Redshaw and W.-H. Sun, Inorg. Chim. Acta., 2012, 385, 21.

6 (a) F. Huang, Z. Sun, S. Du, E. Yue, J. Ba, X. Hu, T. Liang, G. B. Galland and W.-H. Sun, Dalton Trans., 2015, 44, 14281; (b) Z. Sun, F. Huang, M. Qu, E. Yue, I. V. Oleynik, I. I. Oleynik, Y. Zeng, T. Liang, K. Li, W. Zhang and W.-H. Sun, RSC Adv., 2015, 5, 77913. 
7 J. Ba, S. Du, E. Yue, X. Hu, Z. Flisak and W.-H. Sun, RSC Adv., 2015, 5, 32720.

8 Y. Zhang, C. Huang, X. Hao, X. Hu and W.-H. Sun, RSC Adv., 2016, 6, 91401.

9 C. Huang, Y. Zhang, T. Liang, Z. Zhao, X. Hu and W.-H. Sun, New J. Chem., 2016, 40, 9329.

10 (a) Y. He, X. Qiu, J. Klosin, R. Cong, G. R. Roof and D. Redwine, Macromolecules, 2014, 47, 3782; (b) V. Busico, R. Cipullo, N. Friederichs, H. Linssen, A. Segre, V. V. A. Castelli and G. V. D. Velden, Macromolecules, 2005, 38, 6988.

11 (a) A. Smedberg and T. Hjertberg, Polymer, 1997, 38, 4127; (b) T. C. Chung, H. L. Lu and C. L. Lit, Macromolecules, 1994, 27, 7533; (c) M. G. Andersson, M. Jarvid, A. Johansson, S. Gubanski, M. R. StJ. Foreman, C. Müller and M. R. Andersson, Eur. Polym. J., 2015, 64, 101; (d) M. Palmlofa and T. Hjertberg, Polymer, 2000, 41, 6481; (e) X. Jiang, H. Yu, R Frayne, O. Unal and C. M. Strother, Chem. Mater., 2002, 14, 1914; (f) W. Liu, P. Liu, W.-J. Wang, B.-G. Li and S. Zhu, Macromol. React. Eng., 2016, 10, 180.

12 J. H. Groen, M. J. M. Vlaar, P. W. N. M. Van Leeuwen, K. Vriezi and H. Kooijman, J. Organomet. Chem., 1998, 551, 67.

13 E. Yue, L. Zhang, Q. Xing, X.-P. Cao, X. Hao, C. Redshaw and W.-H. Sun, Dalton Trans., 2014, 43, 423.

14 S. A. Svejda and M. Brookhart, Organometallics, 1999, 18, 65.

15 (a) H. Liu, W. Zhao, X. Hao, C. Redshaw, W. Huang and W.-H. Sun, Organometallics, 2011, 30, 2418; (b) H. Liu, W. Zhao, J. Yu, W. Yang, X. Hao, C. Redshaw, L. Chen and W.-H. Sun, Catal. Sci. Technol., 2012, 2, 415; (c) S. Kong, C.-Y. Guo, W. Yang, L. Wang, W.-H. Sun and R. Glaser, J. Organomet. Chem., 2013, 725, 37; (d) C. Wen, S. Yuan, Q. Shi, E. Yue, D. Liu and W.-H. Sun, Organometallics, 2014, 33, 7223; (e) Z. He, Y. Liang, W. Yang, H. Uchino, J. Yu, W.-H. Sun and C. C. Han, Polymer, 2015, 56, 119; (f) S. Du, S. Kong, Q. Shi, J. Mao, C. Guo, J. Yi, T. Liang and W.-H. Sun, Organometallics, 2015, 34, 582

16 W. Zhang, W.-H. Sun, S. Zhang, J. Hou, K. Wedeking, S. Schultz, R. Fröhlich and H. Song, Organometallics, 2006, 25 1961.

17 (a) W. Zhang, W. Chai, W.-H. Sun, X. Hu, C. Redshaw and X. Hao, Organometallics, 2012, 31, 5039; (b) W.-H. Sun, S. Kong, W. Chai, T. Shiono, C. Redshaw, X. Hu, C. Guo and X. Hao, Appl. Catal. A: Gen., 2012, 447.

18 (a) S. Du, Q. Xing, Z. Flisak, E. Yue, Y. Sun and W.-H. Sun, Dalton Trans., 2015, 44, 12282; (b) S. Wang, B. Li, T. Liang, C. Redshaw, Y. Li and W.-H. Sun, Dalton Trans., 2013, 42, 9188.

19 (a) F. Huang, W. Zhang, E. Yue, T. Liang, X. Hu and W.-H. Sun, Dalton Trans., 2016, 45, 657; (b) G. B. Galland, R. Quijada, R. Rolas, G. Bazan and Z. J. A. Komon, Macromolecules, 2002, 35, 339; (c) W.-H. Sun, X. Tang, T. Gao, B. Wu, W. Zhang and H. Ma, Organometallics, 2004, 23, 5037.

20 G. B. Galland, R. F. de Souza, R. S. Mauler and F. F. Nunes, Macromolecules, 1999, 32, 1620.

21 (a) P. H. M. Budzelaar, Comput. Mol. Sci., 2012, 2, 221; (b) D. G. Musaev, R. D. J. Froese, M. Svensson and K. Morokuma, J. Am. Chem. Soc.,1997, 119, 367; (c) L. Deng, P. Margl and T. Ziegler, J. Am. Chem. Soc., 1997, 119, 1094; (d) R. Ribeiro, R. Ruivo, H. Nsiri, S. Norsic, F. D. Agosto, Lionel Perrin and C. Boisson, ACS Catal., 2016, 6, 851; (e) S. A. Svejda, L. K. Johnson and M. Brookhart, J. Am. Chem. Soc., 1999, 121, 10634; (f) D. J. Tempel, L. K. Johnson, R. L. Huff, P. S. White and M. Brookhart, J. Am. Chem. Soc., 2000, 122, 6686; (g) L. H. Shultz, D. J. Tempel and M. Brookhart, J. Am. Chem. Soc., 2001, 123, 11539; (h) K. E. Allen, J. Campos, O. Daugulis and M. Brookhart, ACS Catal., 2015, 5, 456; (i) V. M. Mohring and G. Fink. Angew. Chem. Int. Ed. Engl., 1985, 24, 1001.

22 Z. Flisak and W.-H. Sun, ACS Catal., 2015, 5, 4713.
23 F. Huang, W. Zhang, Y. Sun, X. Hu, G. A. Solan and W.-H. Sun, New J. Chem., 2016, 40, 8012.

24 (a) D. P. Gates, S. A. Svejda, E. Oñate, C. M. Killian, L. K. Johnson, P. S. White and M. Brookhart, Macromolecules, 2000, 33, 2320; (b) J. C. Jenkins and M. Brookhart, J. Am. Chem. Soc., 2004, 126, 5827; (c) S. J. McLain, J. Feldman, E. F. McCord, K. H. Gardner, M. F. Teasley, E. B. Coughlin, K. J. Sweetman, L. K. Johnson and M. Brookhart, Macromolecules, 1998, 31, 6705; (d) M. D. Leatherman, S. A. Svejda, L. K. Johnson and M. Brookhart, J. Am. Chem. Soc., 2003, 125, 3068.

25 W. Scherer and G. S. McGrady, Angew. Chem. Int. Ed., 2004, 43, 1782.

26 G. M. Sheldrick, SHELXTL-97, Program for the Refinement of Crystal Structures, University of Göttingen, Germany, 1997. 